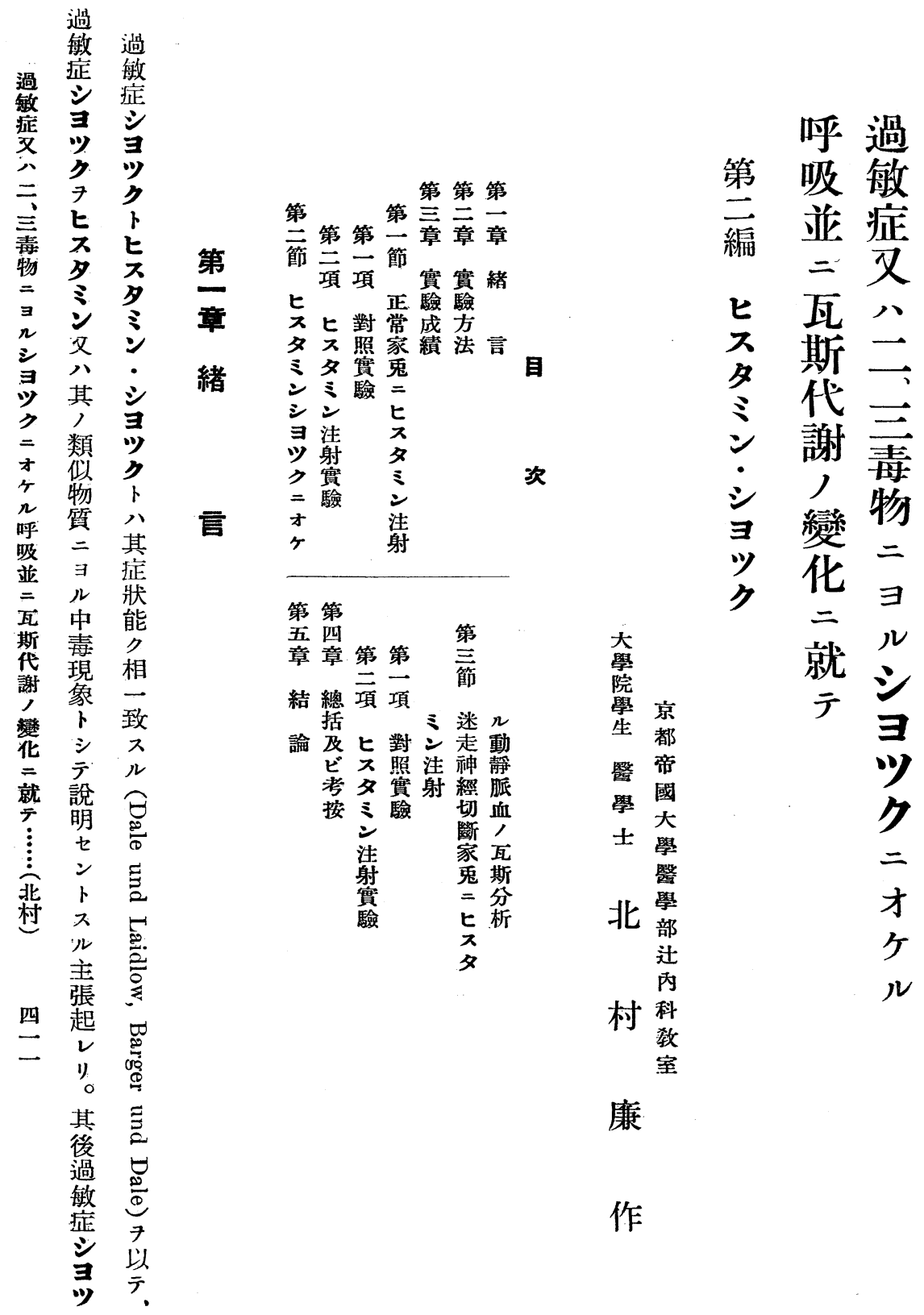




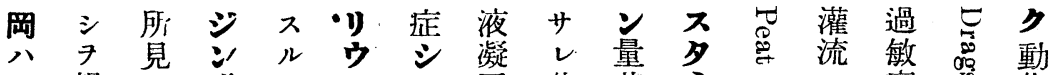

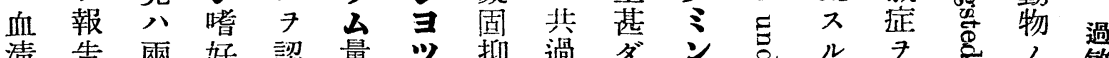

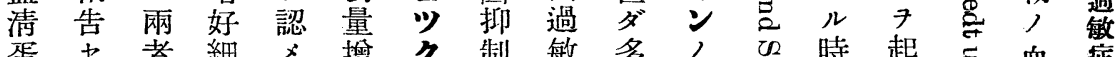

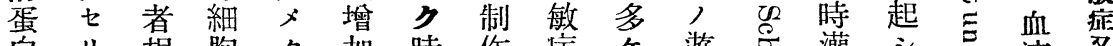

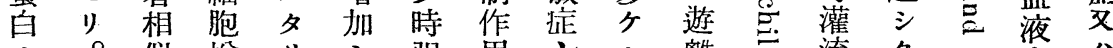
人。似增り 布子ル

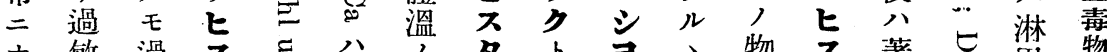
オ敏過 ス

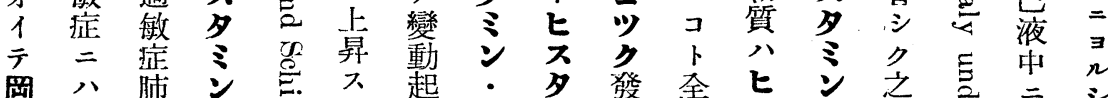

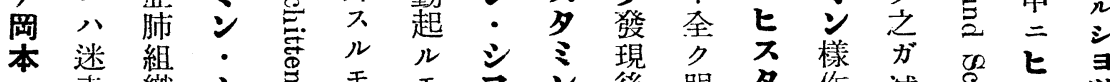

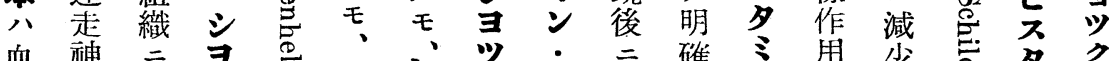

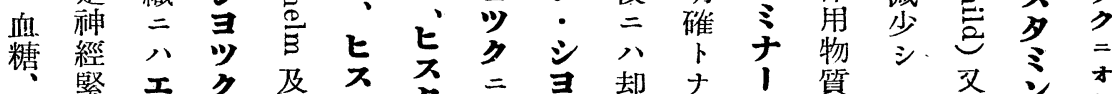

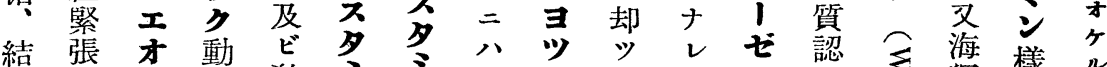

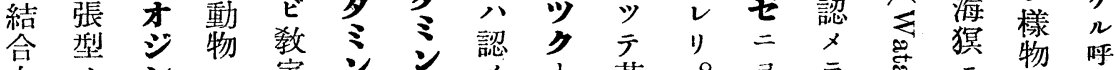
血了

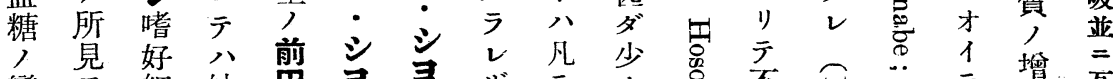

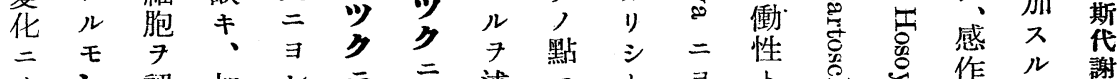
才 七 認 加 1 ス厶之代分認心゙於云レナ、手卜變

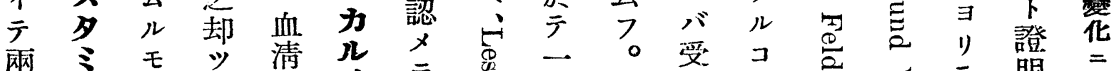
霫 間

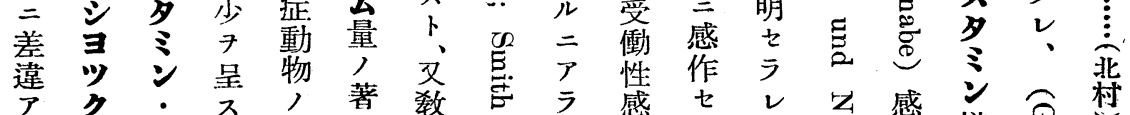

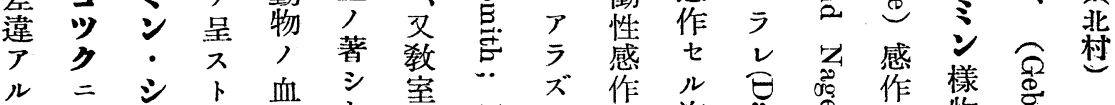

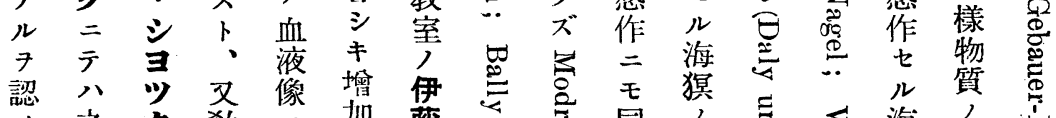

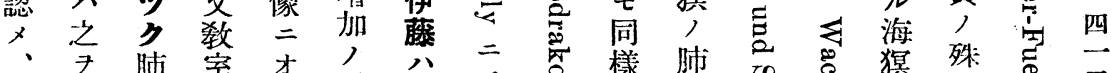

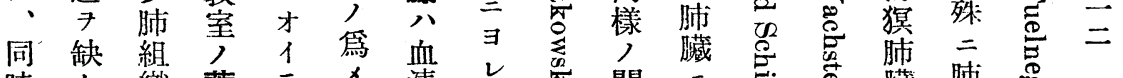
時 ケ 織幕

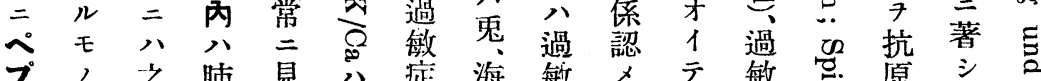
プ, 之肺見公症海整 $x$ 整哥原 シ

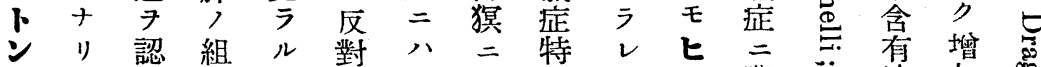
卜 00 織、

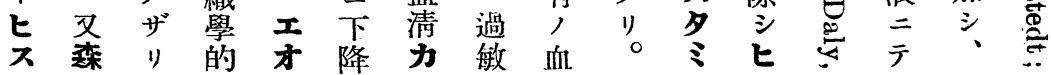



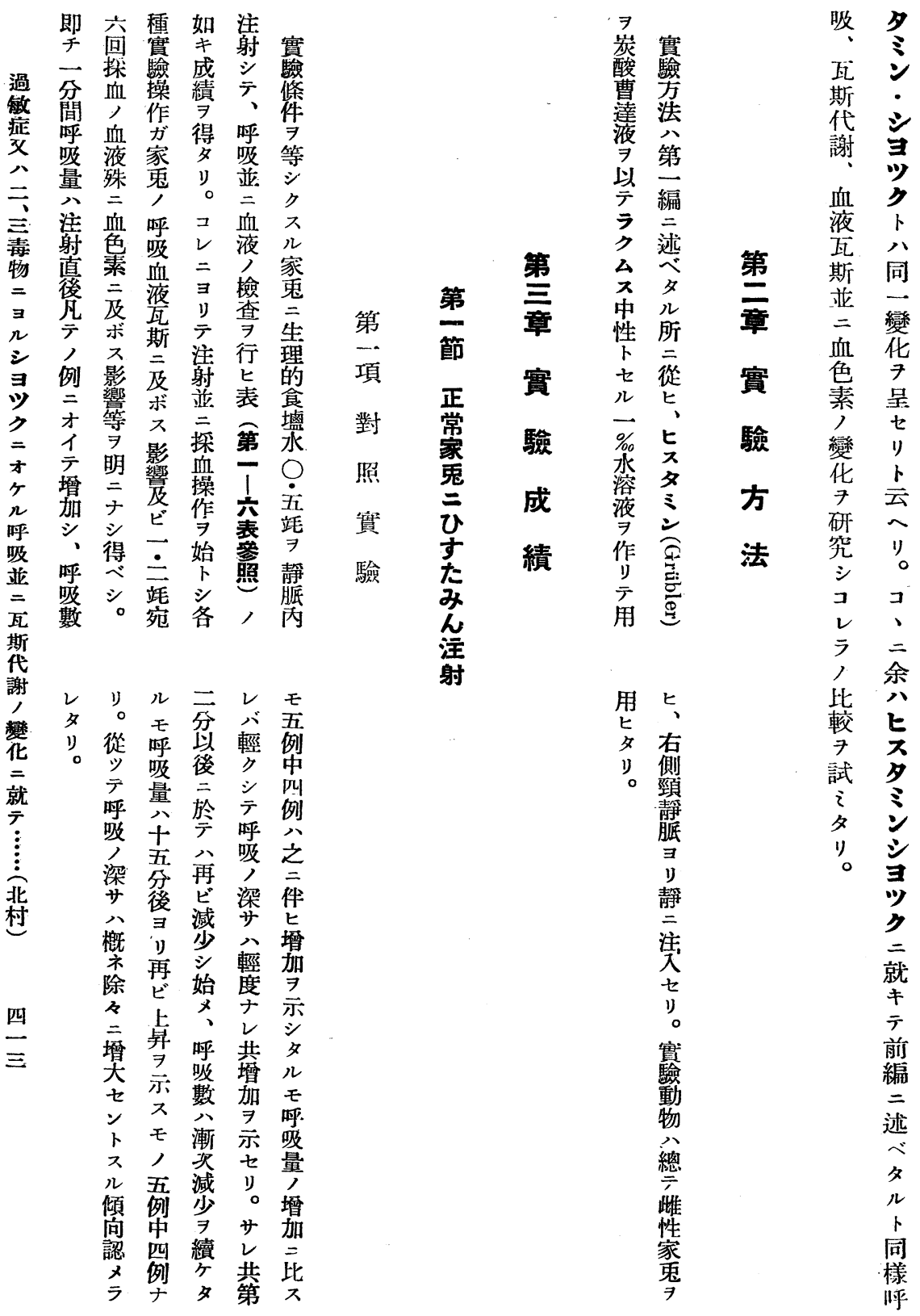


\begin{tabular}{|c|c|}
\hline 官 & 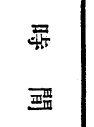 \\
\hline 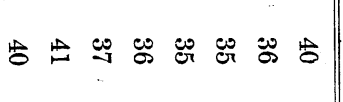 & 武 \\
\hline 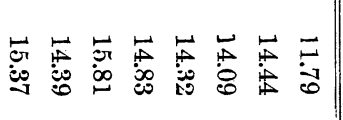 & 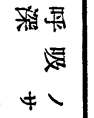 \\
\hline 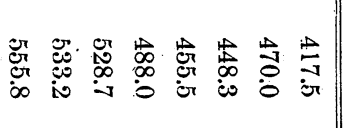 & 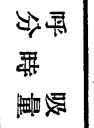 \\
\hline 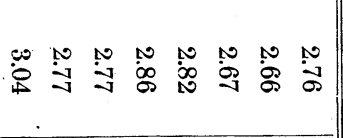 & 㩆 \\
\hline 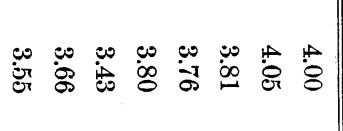 & 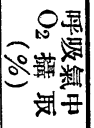 \\
\hline 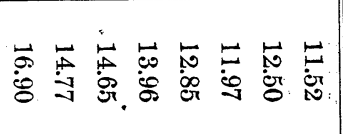 & 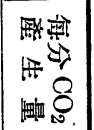 \\
\hline 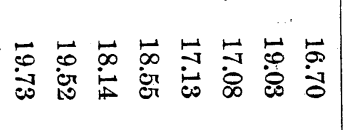 & 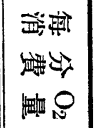 \\
\hline 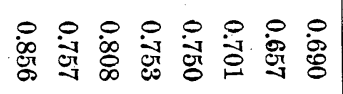 & 帠 \\
\hline$\vec{N}$ जै औี & 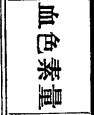 \\
\hline 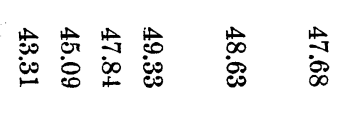 & 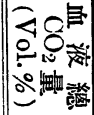 \\
\hline 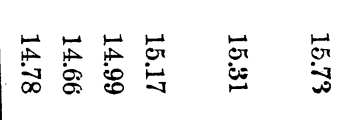 & 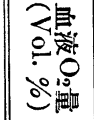 \\
\hline
\end{tabular}

\begin{tabular}{|c|c|}
\hline 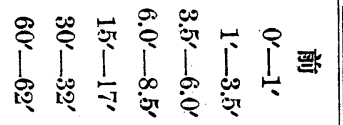 & 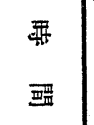 \\
\hline 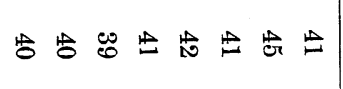 & 丞 \\
\hline 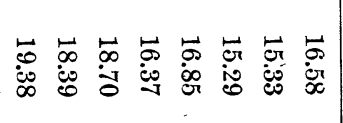 & 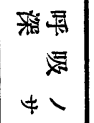 \\
\hline 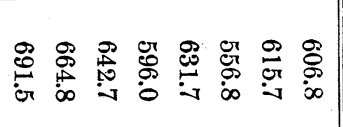 & 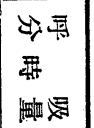 \\
\hline 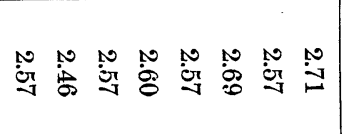 & 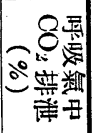 \\
\hline 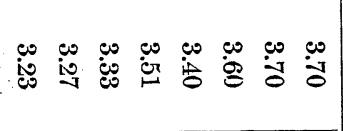 & 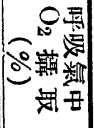 \\
\hline 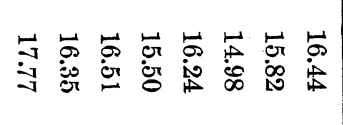 & 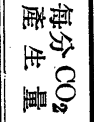 \\
\hline 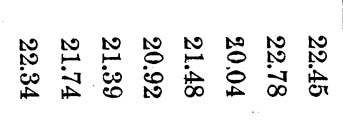 & 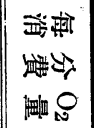 \\
\hline 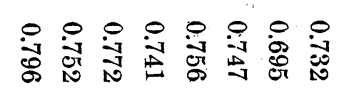 & 寻 \\
\hline$\vec{\varpi} \vec{N}$ & 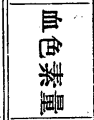 \\
\hline 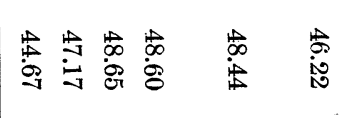 & 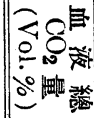 \\
\hline 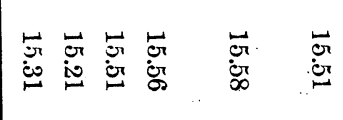 & 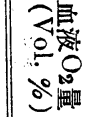 \\
\hline
\end{tabular}




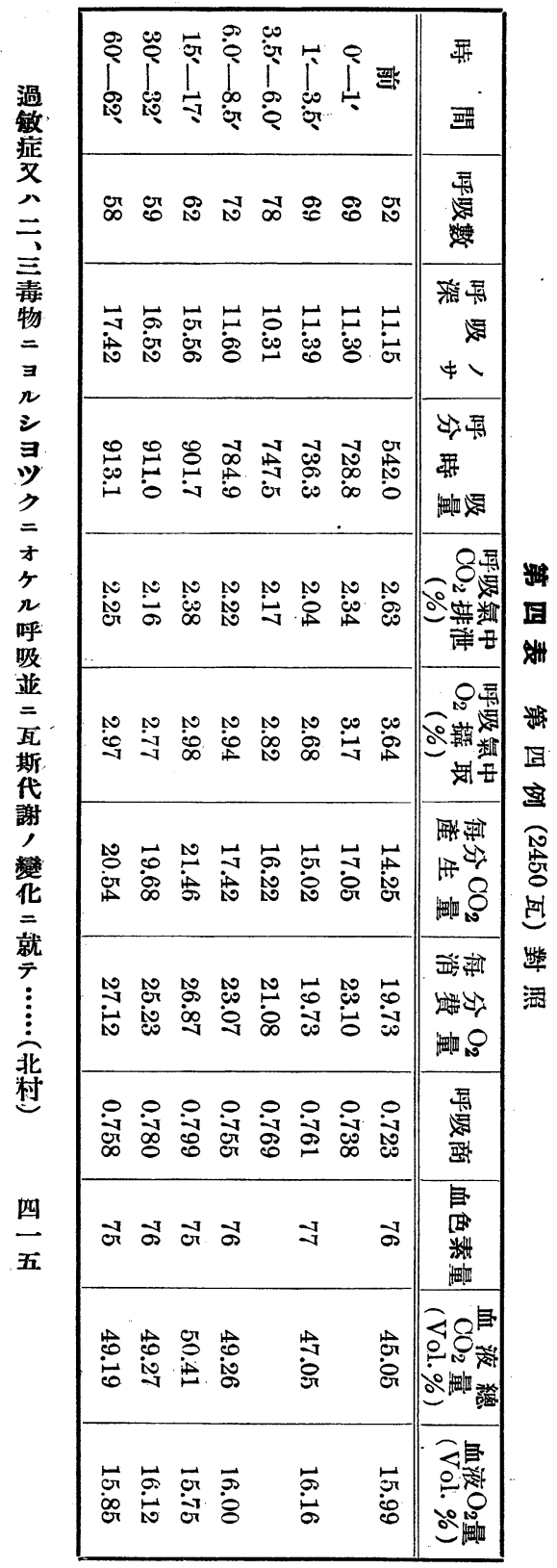

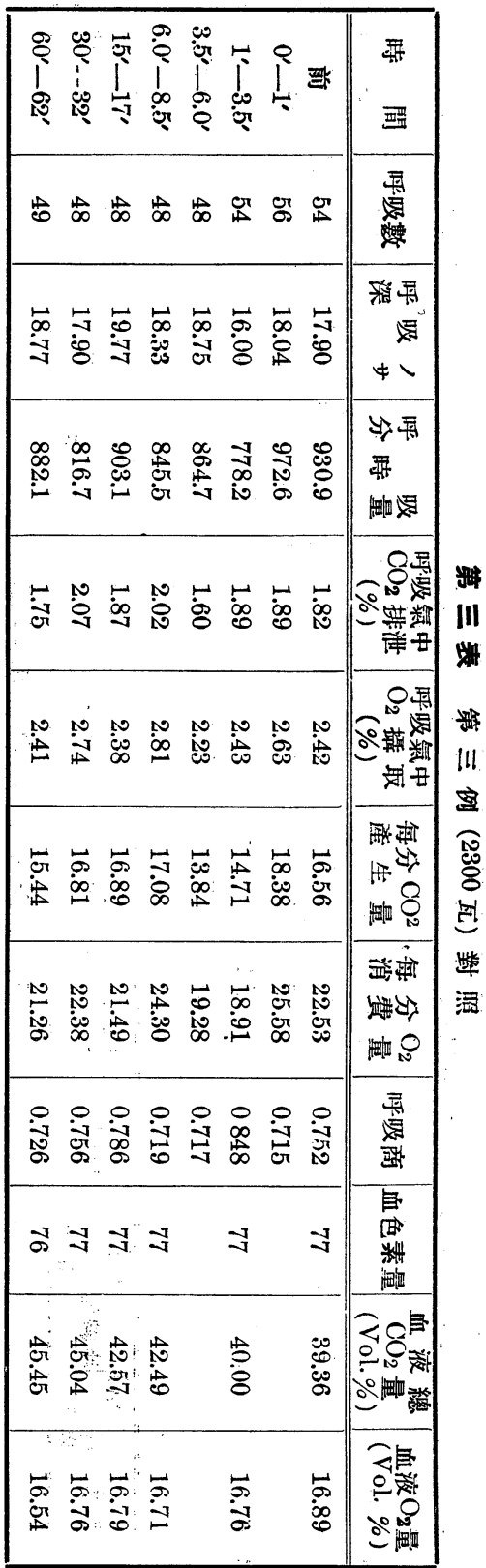




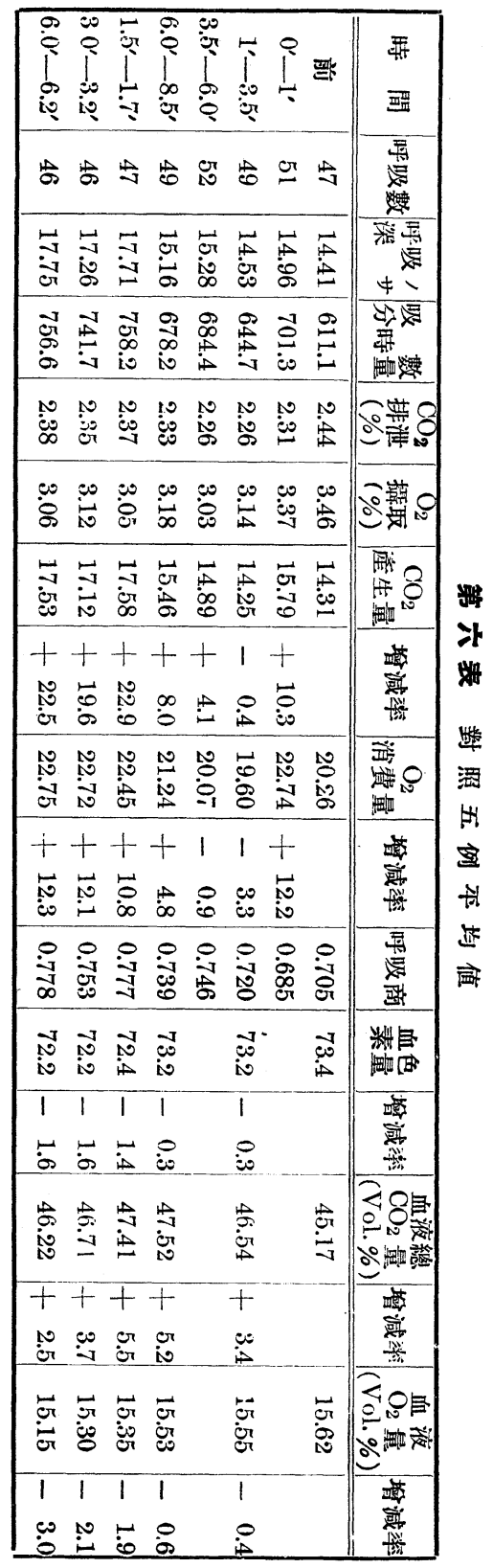

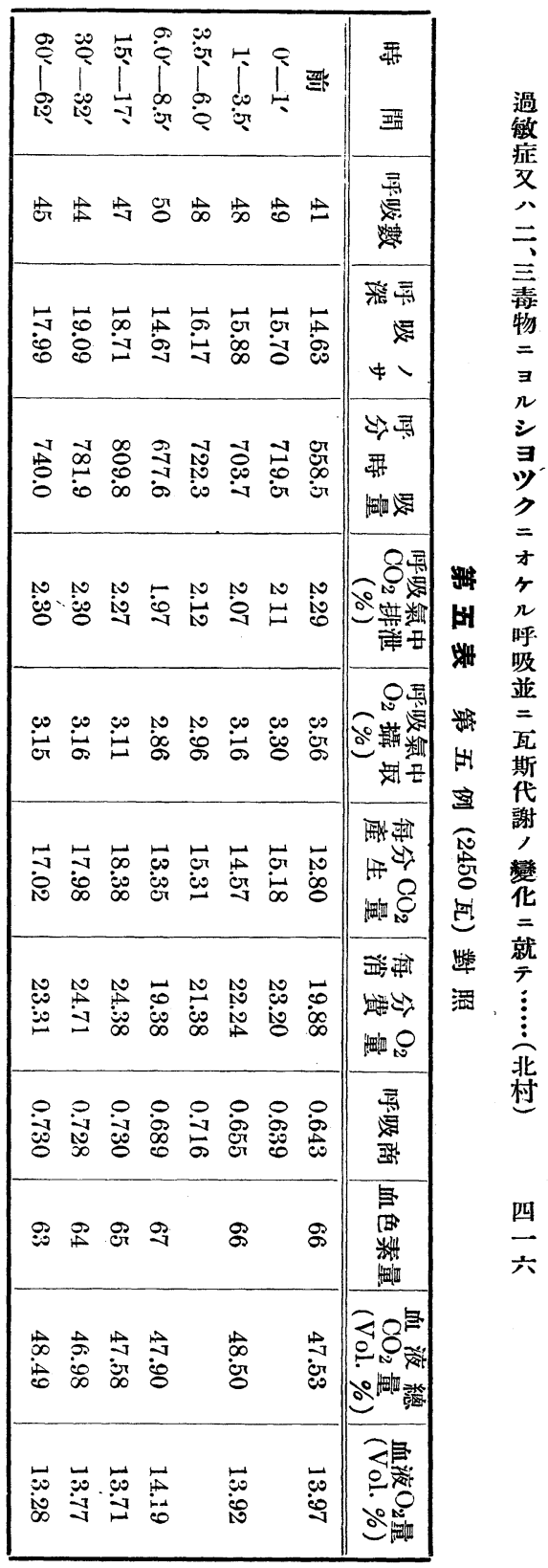




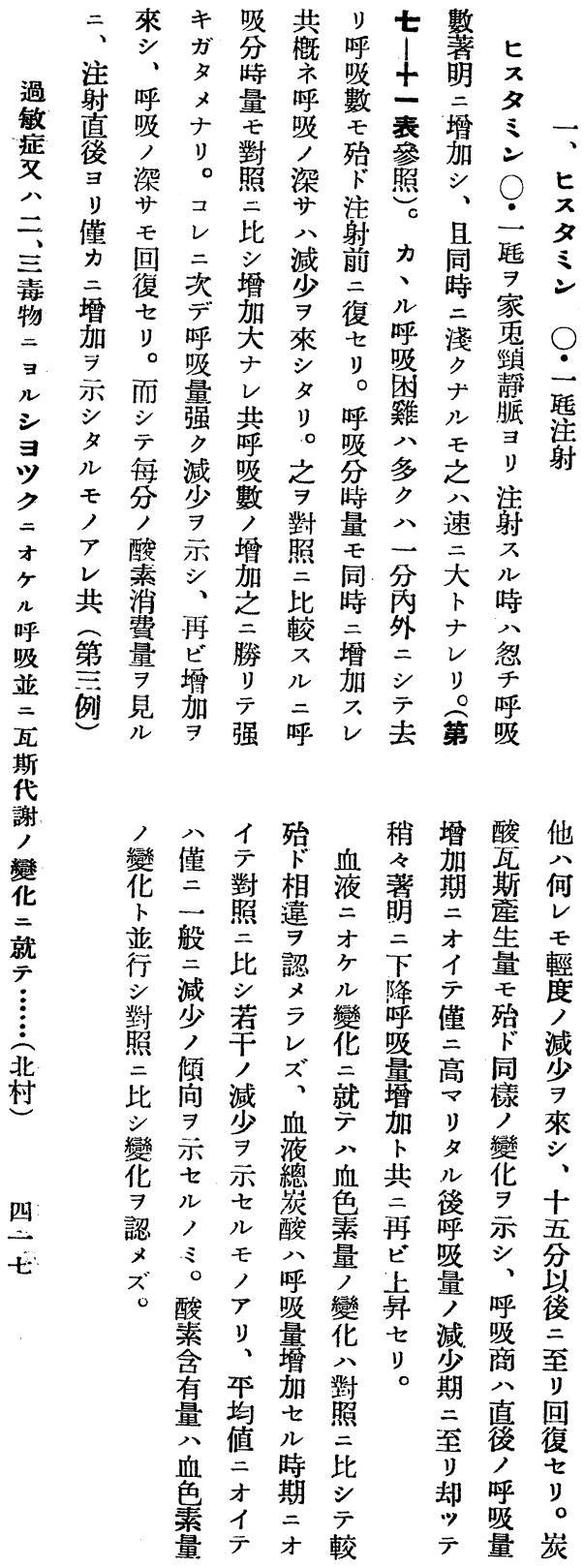

摇瓦量とセ少

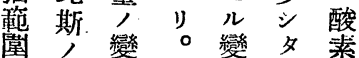

呙呼华而化儿滔

三氣 $上 \exists$ 後費

$\boldsymbol{~}=$ 相 $テ$ 示除量

り排件酸 シ 々

キ泄へ素多二直

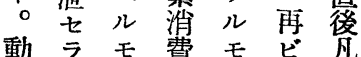

胍儿酸量呼增宁

血、素並吸加

$=\%, 三$ 商

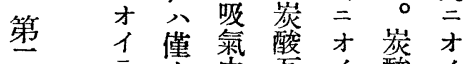

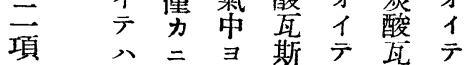

血減 ”虐分斯輕

飞急劣攝告漸蒝度

务示等增量增

第七ラ變大是妿

四ルル化入㱠七

回モル公儿点儿

注採輕 \% 呼倾之干

射䁲度炭分向晋直

驗後動酸永年普減

得實和 7 樑蹱

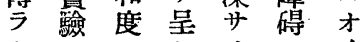

$几= \pm シ, 八 1$

べオ八夕霄無 フ

”。 1 繁 2 加、視漸

背變衁另得減

位化色ナ今少

固于素ルル七

定キ減二べル

更少至 シ 至

氣卜ヨ再總均

捕認儿ビ炭

集希酸減酸六

㯰今容

三、量、酸漸過

ル減㟬素资

呼, 少含增 ズ

吸 = 君有加

障 三顧量 七

碍 慮宅儿探

無熧不漸忘血

覭宁命減吸 


\begin{tabular}{|c|c|}
\hline 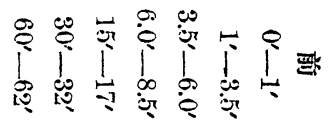 & 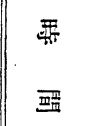 \\
\hline 岕 芯 心 & 衰 \\
\hline 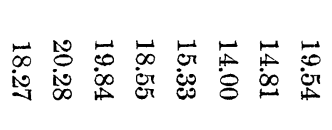 & 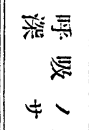 \\
\hline 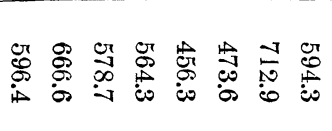 & 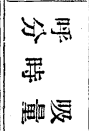 \\
\hline 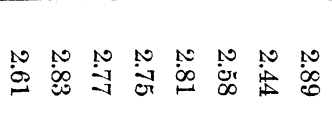 & 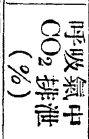 \\
\hline 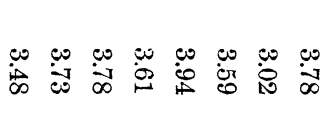 & 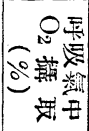 \\
\hline 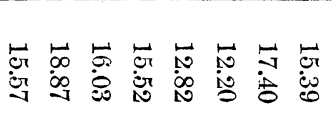 & 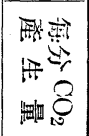 \\
\hline 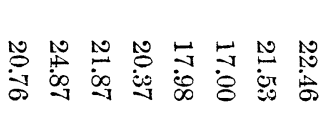 & 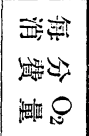 \\
\hline 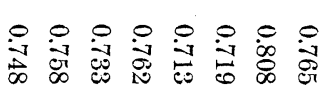 & 善 \\
\hline 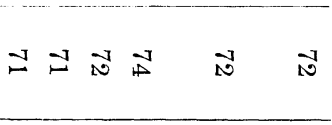 & 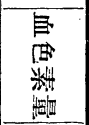 \\
\hline 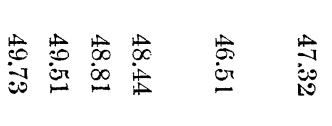 & 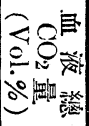 \\
\hline 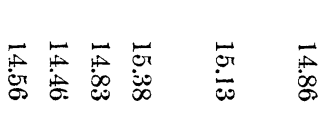 & 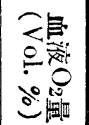 \\
\hline
\end{tabular}

\begin{tabular}{|c|c|}
\hline 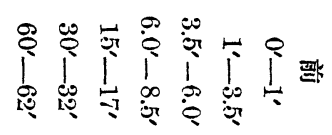 & 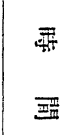 \\
\hline$\stackrel{\infty}{\infty} \underset{\infty}{\infty} \stackrel{\infty}{\infty} \stackrel{\infty}{\mapsto} \& \vec{\infty} \stackrel{\infty}{\mathbb{N}}$ & 娡 \\
\hline 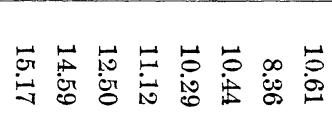 & 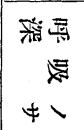 \\
\hline 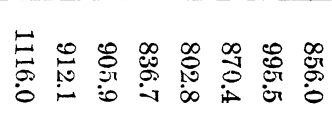 & 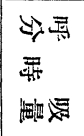 \\
\hline ن & 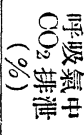 \\
\hline 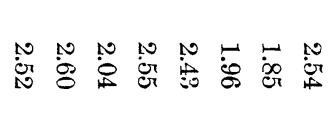 & 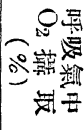 \\
\hline 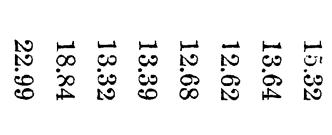 & 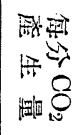 \\
\hline 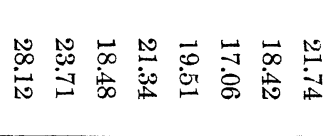 & 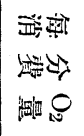 \\
\hline 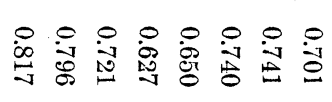 & 憲 \\
\hline అల & 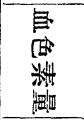 \\
\hline 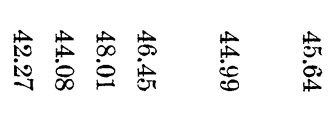 & 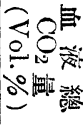 \\
\hline 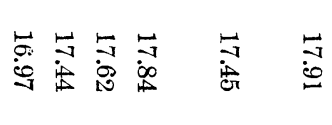 & 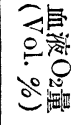 \\
\hline
\end{tabular}




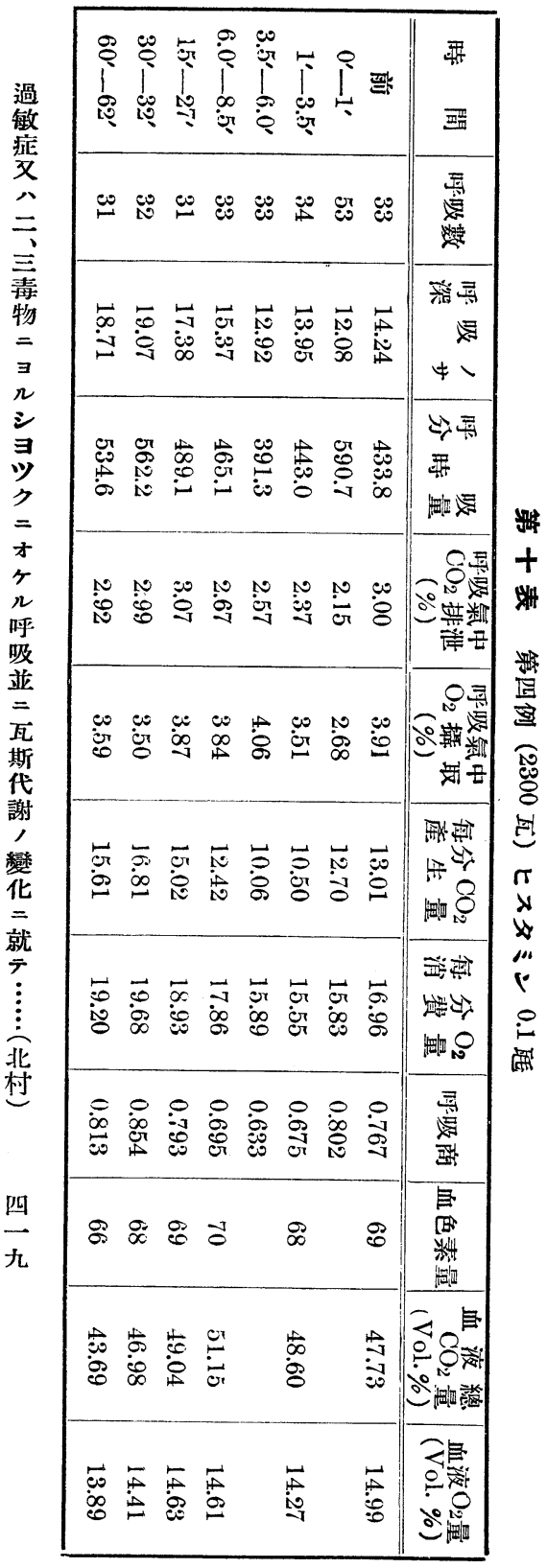

\begin{tabular}{|c|c|}
\hline 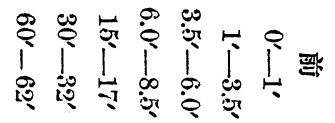 & 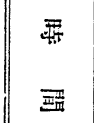 \\
\hline 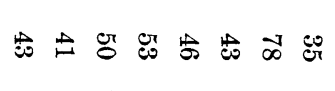 & 焉 \\
\hline 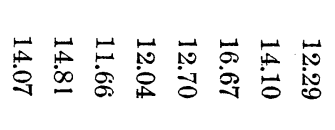 & 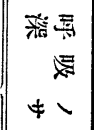 \\
\hline 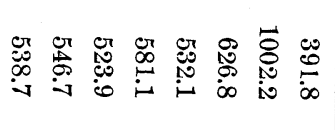 & 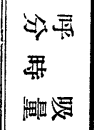 \\
\hline 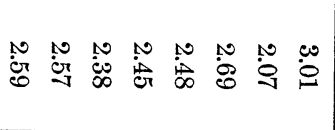 & 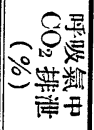 \\
\hline 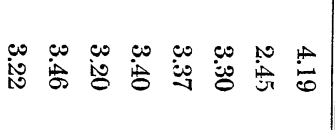 & 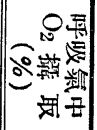 \\
\hline 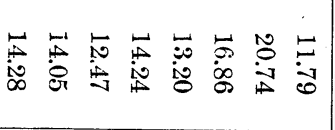 & 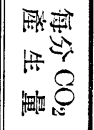 \\
\hline 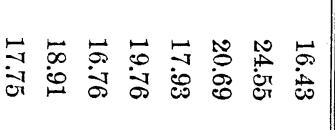 & 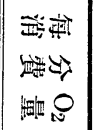 \\
\hline 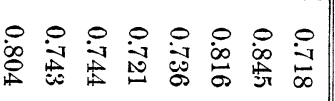 & $\begin{array}{l}\text { 震 } \\
\text { 飽 }\end{array}$ \\
\hline 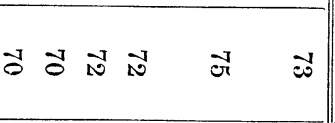 & 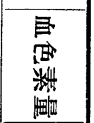 \\
\hline 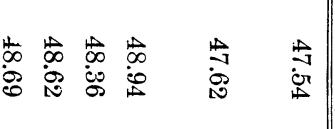 & 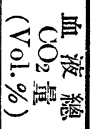 \\
\hline 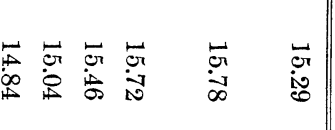 & 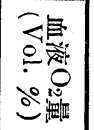 \\
\hline
\end{tabular}




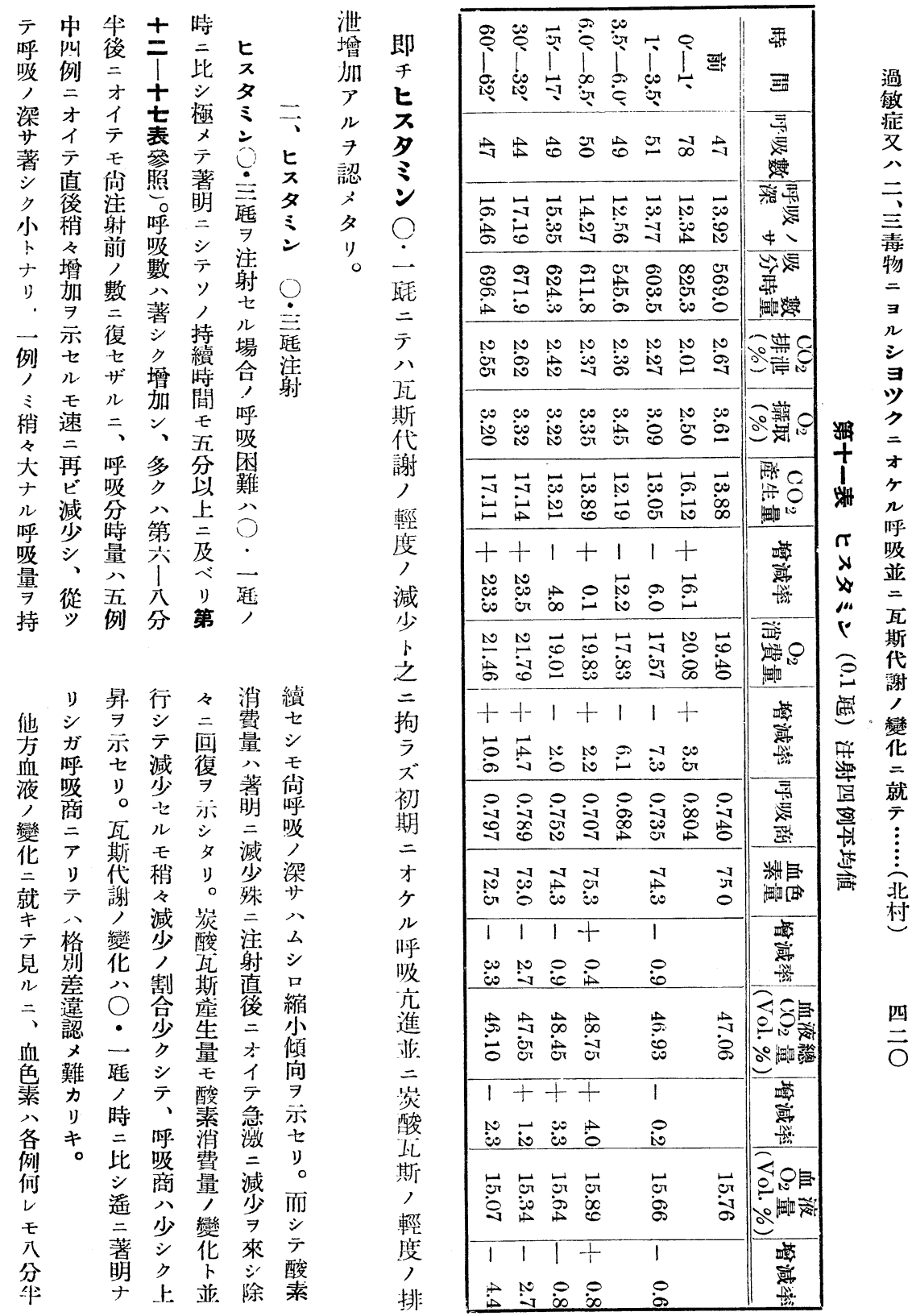




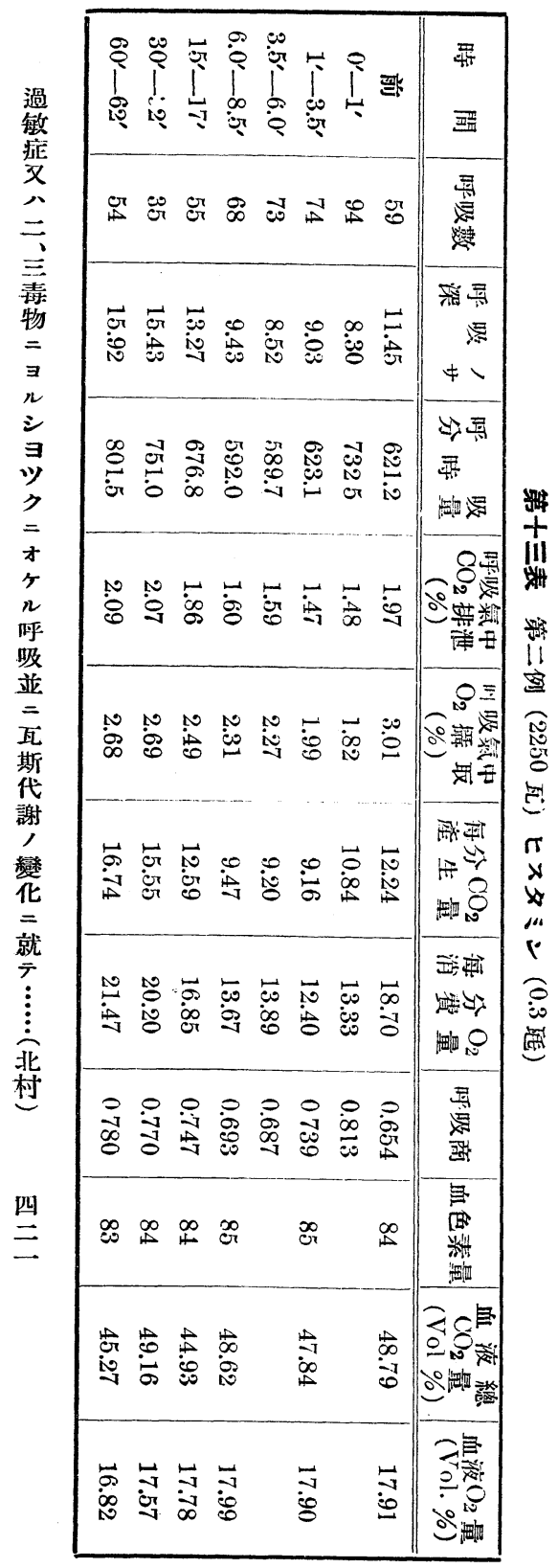

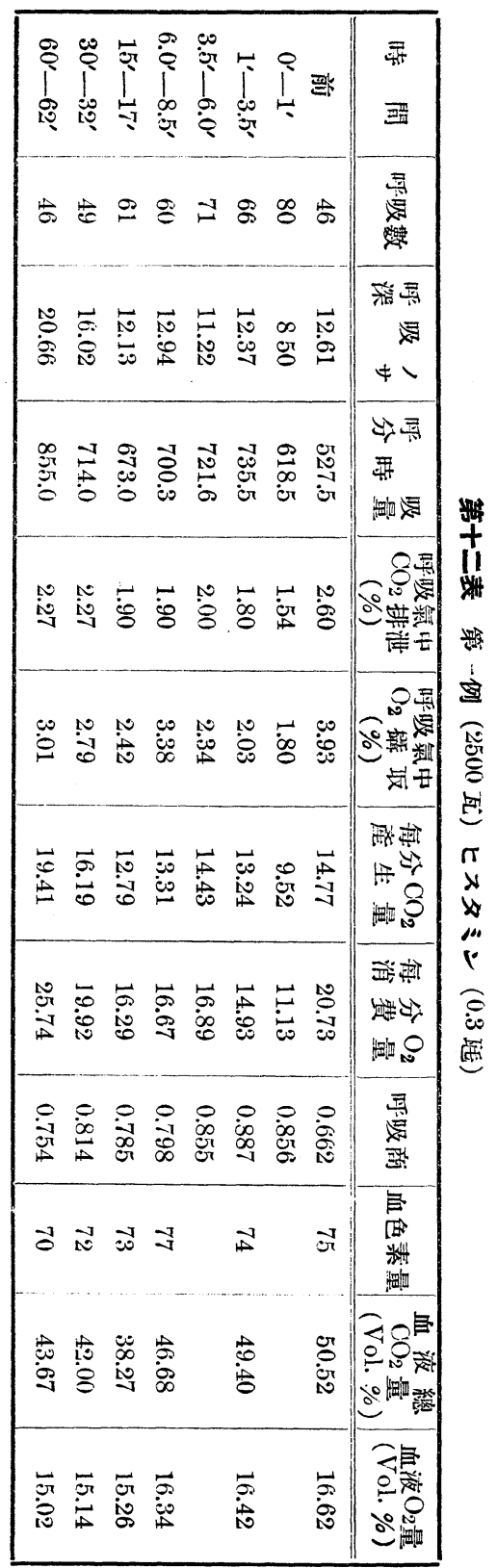




\begin{tabular}{|c|c|}
\hline 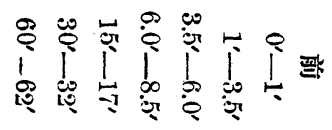 & $\begin{array}{l}\text { 패 } \\
\text { 표ㅍㅛㅐ }\end{array}$ \\
\hline 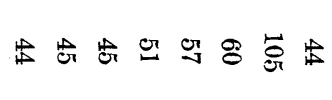 & 胥 \\
\hline 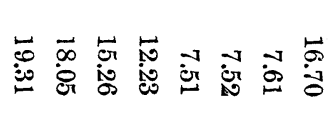 & $\begin{array}{l}\text { 籍馬 } \\
4 \\
4\end{array}$ \\
\hline 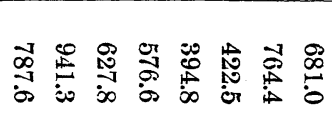 & 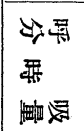 \\
\hline 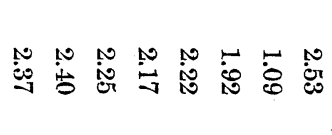 & 野 \\
\hline 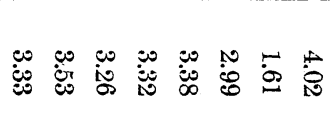 & 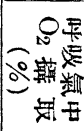 \\
\hline 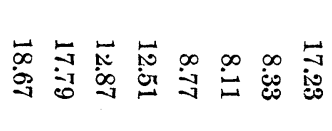 & 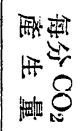 \\
\hline 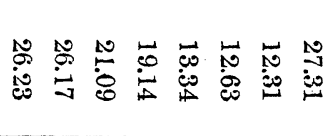 & 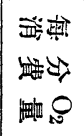 \\
\hline 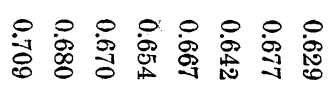 & 門 \\
\hline 요 엉 \& & 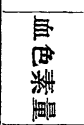 \\
\hline 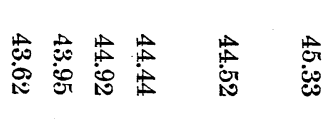 & 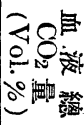 \\
\hline 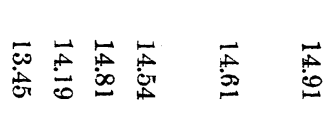 & 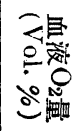 \\
\hline
\end{tabular}

\begin{tabular}{|c|c|}
\hline 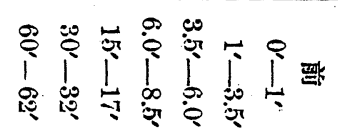 & 표표 \\
\hline$\infty$ ஸ્ & 閟 \\
\hline 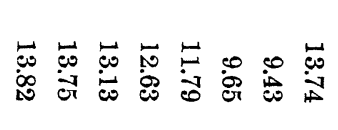 & 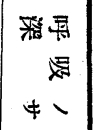 \\
\hline 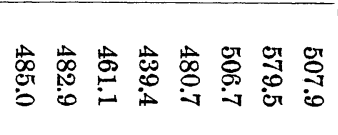 & 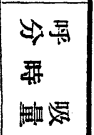 \\
\hline 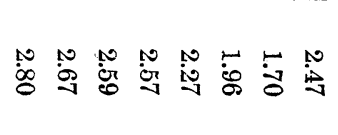 & 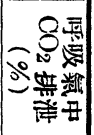 \\
\hline 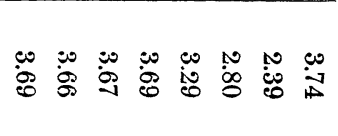 & 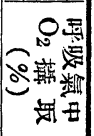 \\
\hline 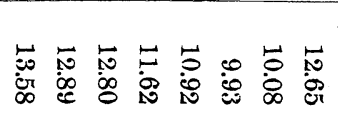 & 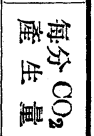 \\
\hline 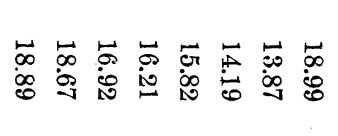 & 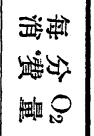 \\
\hline 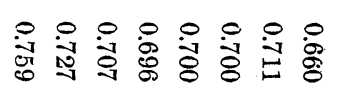 & 余 \\
\hline 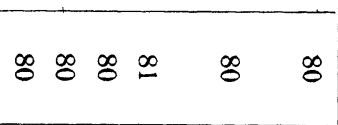 & 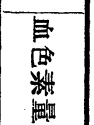 \\
\hline 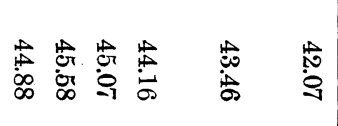 & 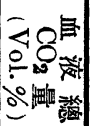 \\
\hline 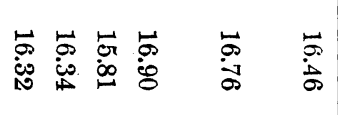 & 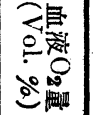 \\
\hline
\end{tabular}




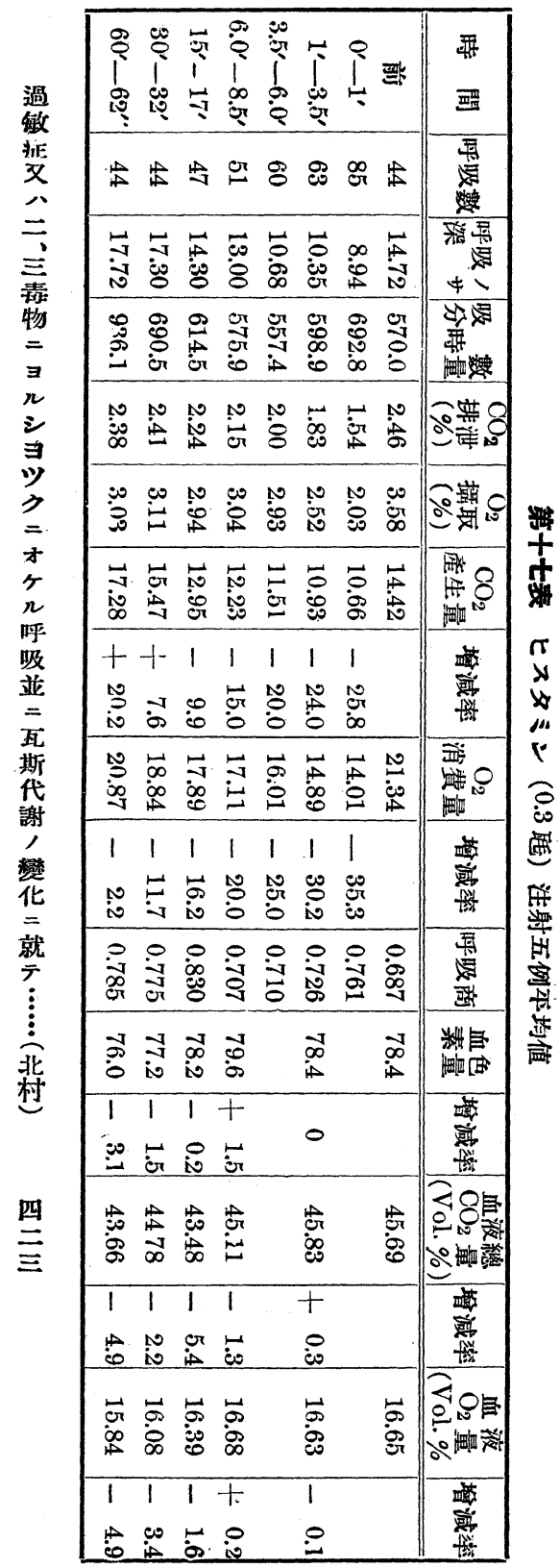

\begin{tabular}{|c|c|}
\hline 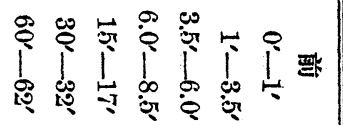 & 푤 \\
\hline 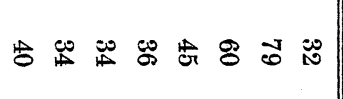 & 謇 \\
\hline 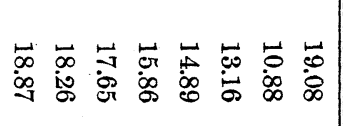 & 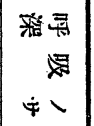 \\
\hline 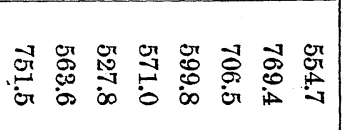 & 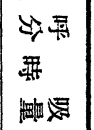 \\
\hline 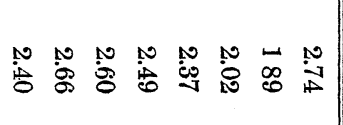 & 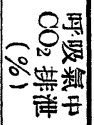 \\
\hline 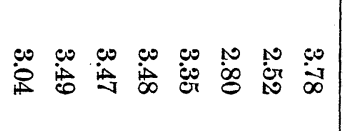 & 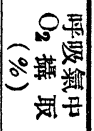 \\
\hline 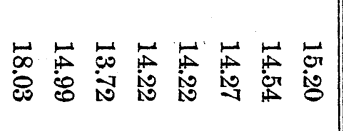 & 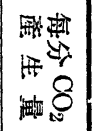 \\
\hline 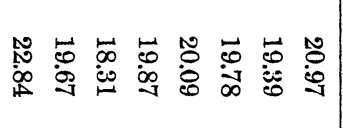 & 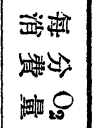 \\
\hline 品 & 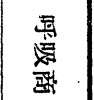 \\
\hline 必 念 の & 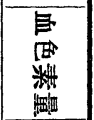 \\
\hline 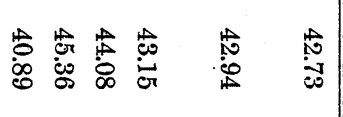 & 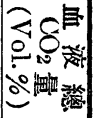 \\
\hline 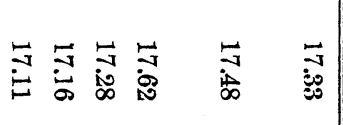 & 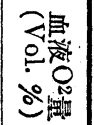 \\
\hline
\end{tabular}




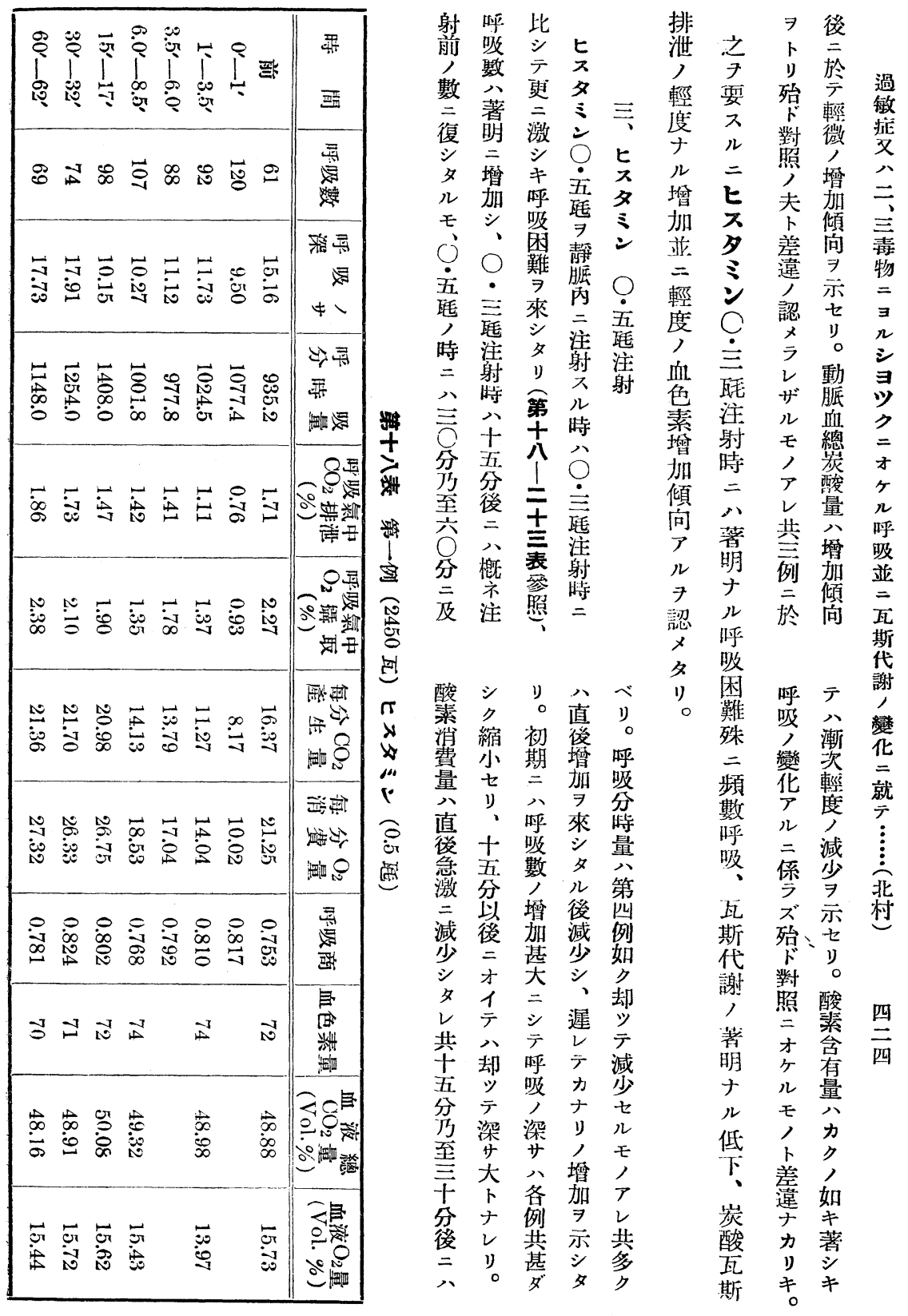




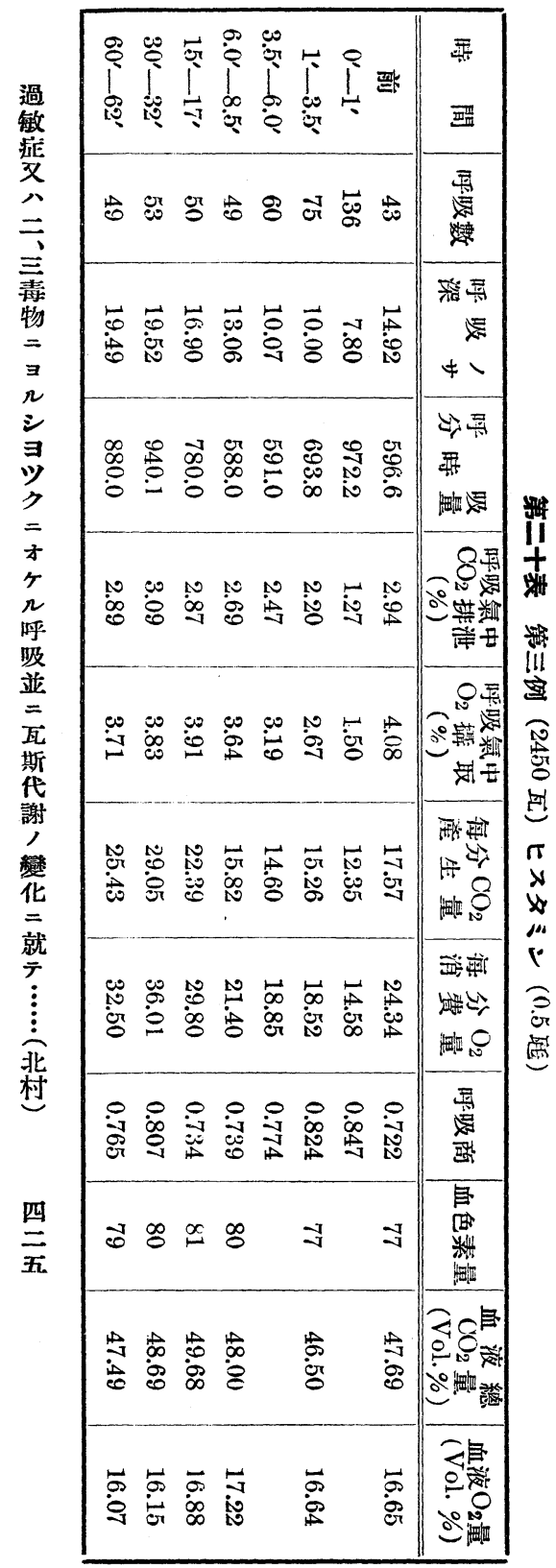

\begin{tabular}{|c|c|}
\hline 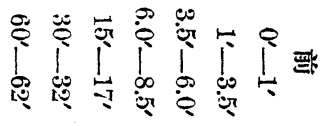 & 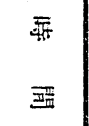 \\
\hline 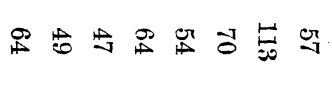 & 畄 \\
\hline 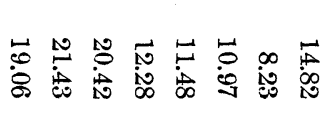 & 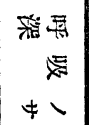 \\
\hline 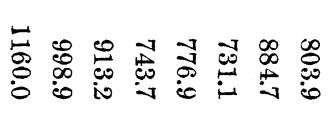 & 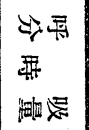 \\
\hline 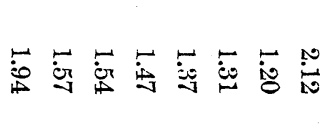 & 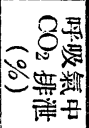 \\
\hline 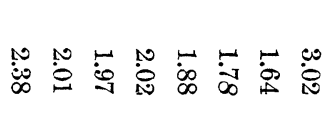 & 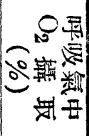 \\
\hline 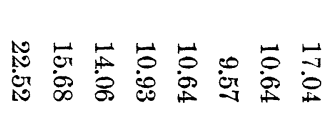 & 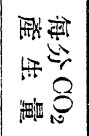 \\
\hline 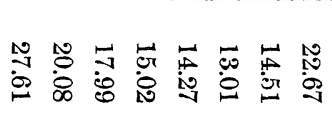 & 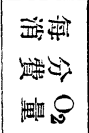 \\
\hline 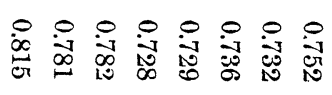 & 蛋 \\
\hline 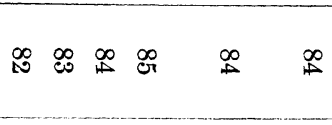 & 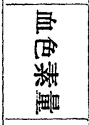 \\
\hline 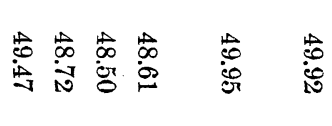 & 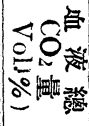 \\
\hline 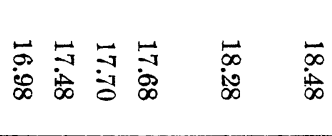 & 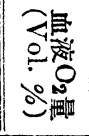 \\
\hline
\end{tabular}




\begin{tabular}{|c|c|}
\hline 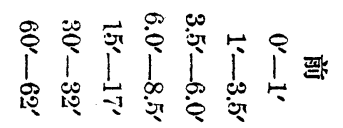 & 政 \\
\hline 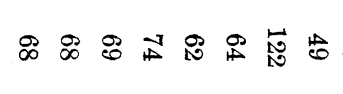 & 衰 \\
\hline 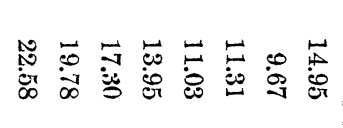 & 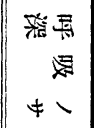 \\
\hline 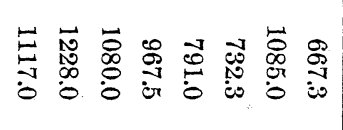 & 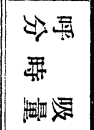 \\
\hline 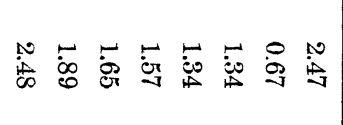 & 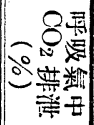 \\
\hline 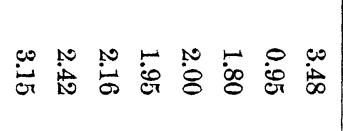 & 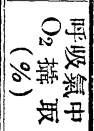 \\
\hline 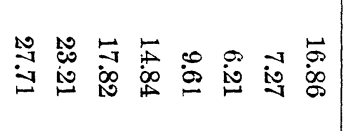 & 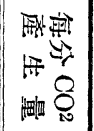 \\
\hline 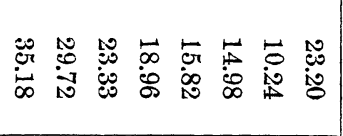 & 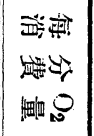 \\
\hline 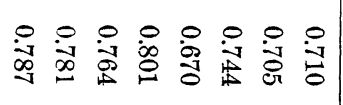 & 霆 \\
\hline $\mathscr{B}: \&$ & 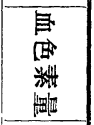 \\
\hline 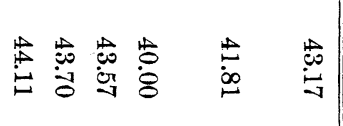 & 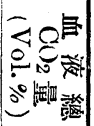 \\
\hline 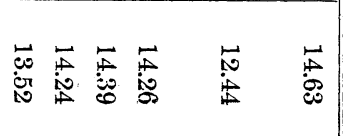 & 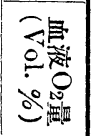 \\
\hline
\end{tabular}

\begin{tabular}{|c|c|}
\hline 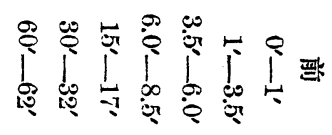 & 표표 \\
\hline 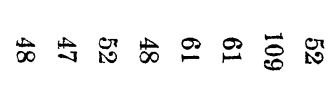 & 羊 \\
\hline 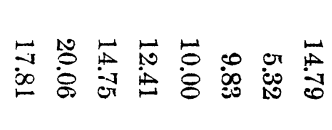 & 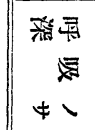 \\
\hline 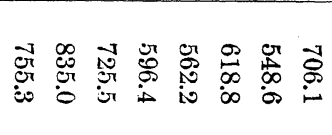 & 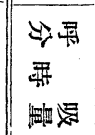 \\
\hline 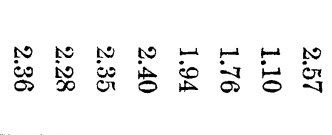 & 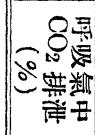 \\
\hline 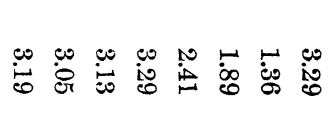 & $\mid$ \\
\hline 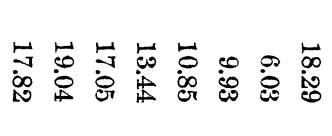 & 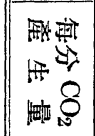 \\
\hline 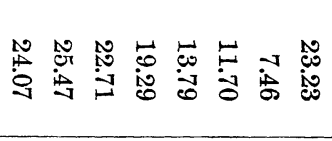 & 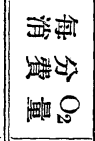 \\
\hline 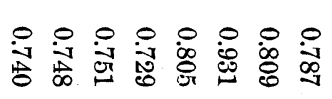 & 蛋 \\
\hline 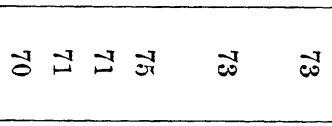 & 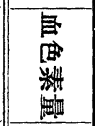 \\
\hline 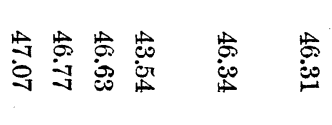 & 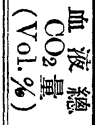 \\
\hline 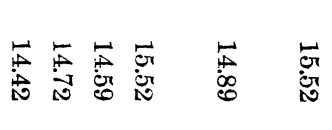 & 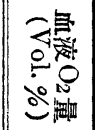 \\
\hline
\end{tabular}




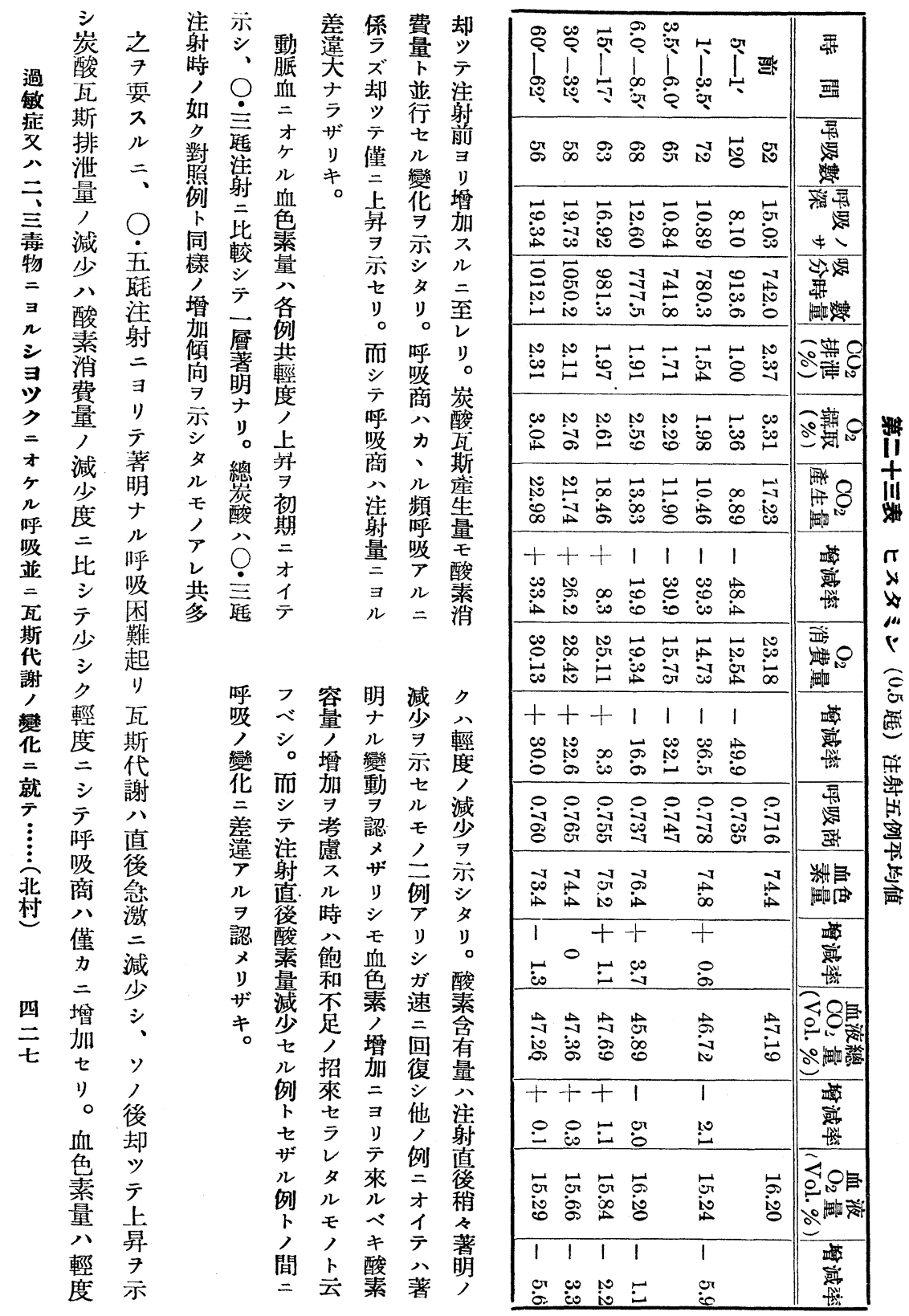


第二十四表 動並二静脈血／血液瓦斯

\begin{tabular}{|c|c|c|c|c|c|c|c|c|c|}
\hline \multirow{2}{*}{ 例 } & \multirow{2}{*}{$\begin{array}{c}\text { ヒスタミン量 } \\
\text { (矮) }\end{array}$} & \multirow{2}{*}{ 瓦 斯 } & \multirow{2}{*}{ 血液 } & \multicolumn{2}{|c|}{ 注 射 前 } & \multicolumn{2}{|c|}{ 二 分 後 } & \multicolumn{2}{|c|}{ 八 分 後 } \\
\hline & & & & (Vol. \%) & 筫減 & (Vol. $\%)$ & 增減 & (Vol. $\frac{\text { 量 }}{\text { (V) }}$ & 燴減 \\
\hline \multirow[t]{2}{*}{1} & 0.3 & 總炭酸 & 青咅脈血 & 46.34 & & 47.27 & & 45.02 & \\
\hline & & 酸 素 & " & 9.51 & & 9.87 & & 7.64 & \\
\hline \multirow[t]{4}{*}{2} & 0.35 & 總炭酸 & 靜脈血 & 46.55 & & 48.87 & & 51.93 & \\
\hline & & " & 動脈血 & 41.70 & 4.00 & 40.06 & 0.01 & 42.87 & 8.00 \\
\hline & & 酸 素 & 静脈血 & 10.64 & & 9.18 & & 8.10 & \\
\hline & & "I & 動脈血 & 16.84 & & 16.04 & & 16.84 & \\
\hline \multirow[t]{4}{*}{3} & 0.3 & 總炭酸 & 靜脈血 & 51.63 & & 55.40 & & 54.44 & \\
\hline & & "I & 動脈血 & 45.41 & & 47.18 & & 49.26 & \\
\hline & & 酸 素 & 靜脈血 & 9.69 & 420 & 8.86 & & 8.77 & 170 \\
\hline & & "I & 動脈血 & 14.08 & & 14.06 & & 13.55 & \\
\hline
\end{tabular}

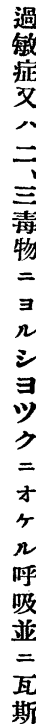

斯

例 $匚$ 輕混夕二左如脈，分二就

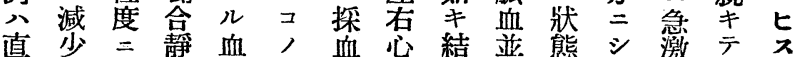

後殊 增胍夜表七臟果 $=$

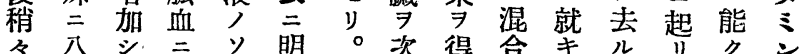

增分八才レナ子多静概 7 肺知!

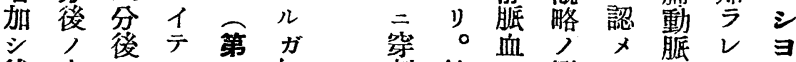

後方 $=$ 八士如刺第二變夕並夕当

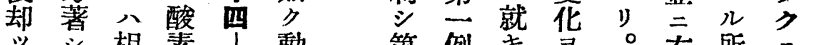

泪素 第例動 7 。右所

テッ當含十㭽 公テ推コ吢二際

少減減有八血例右血知、少

シ少少量素䊼会寉七公强テ强

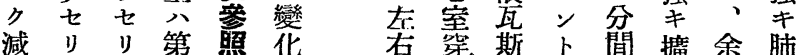

減 。

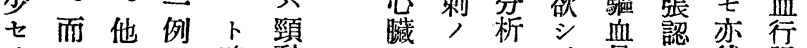

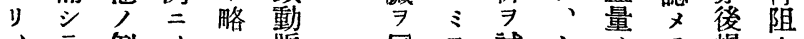

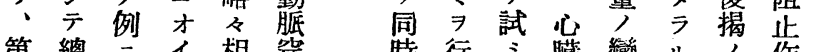

第總

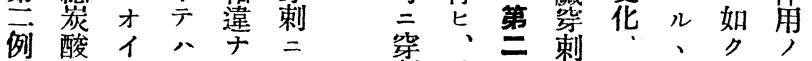

動ひキル

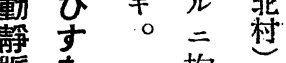

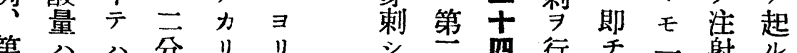

第 公 八分 リ

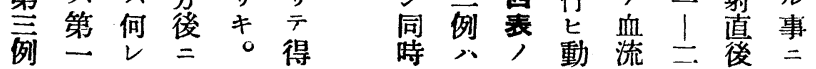

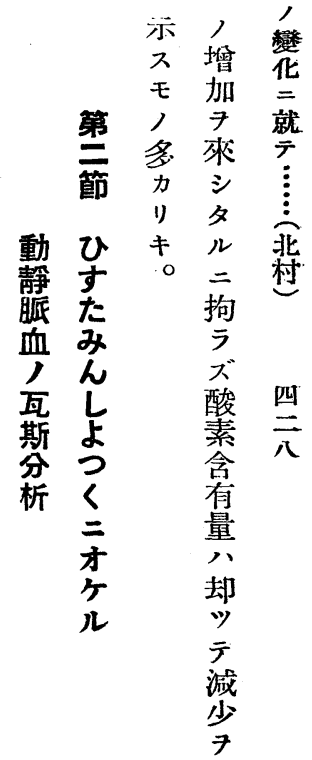




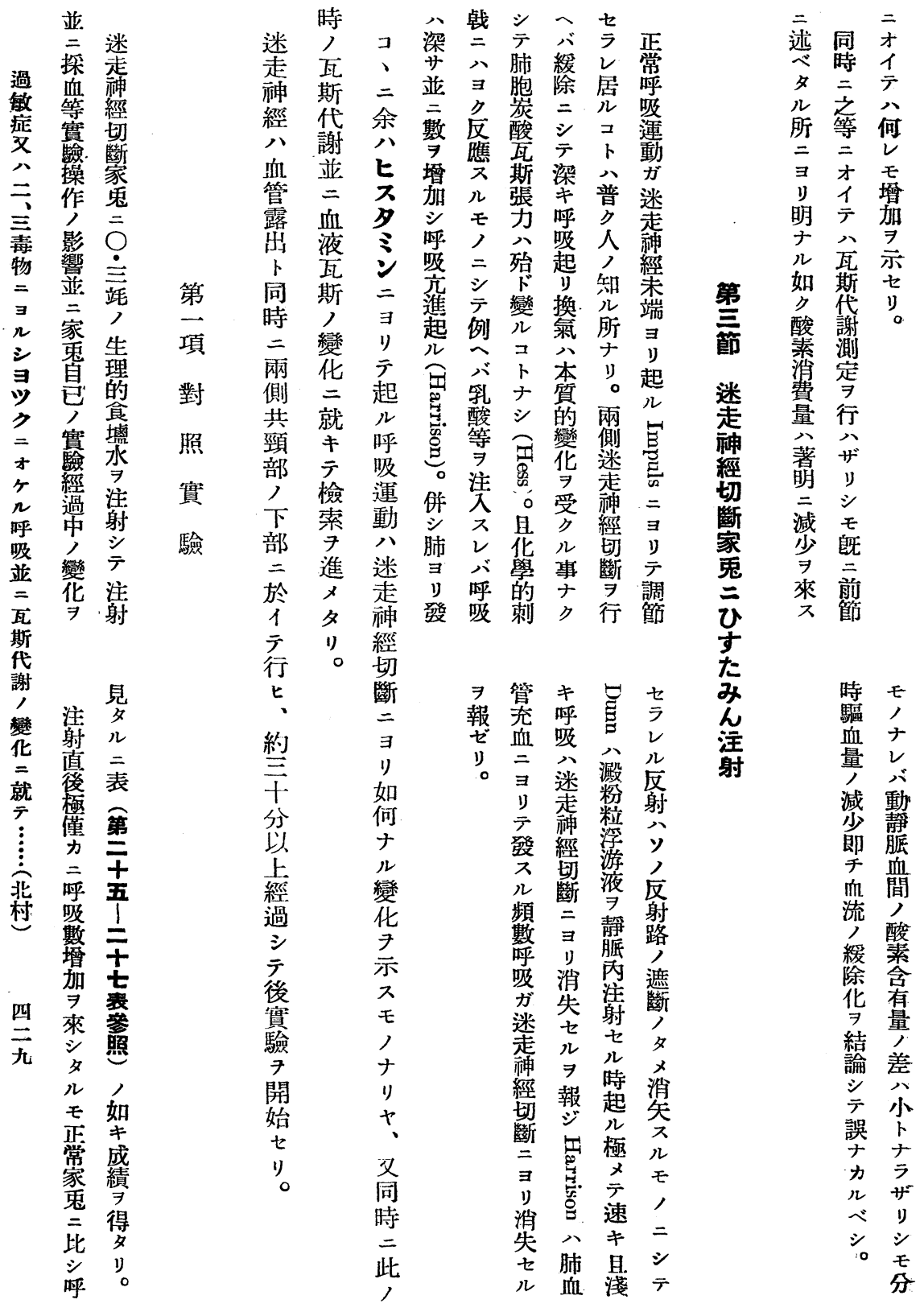




\begin{tabular}{|c|c|}
\hline 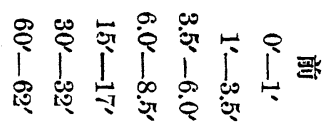 & $\begin{array}{l}\text { 器 } \\
\text { 轠 }\end{array}$ \\
\hline 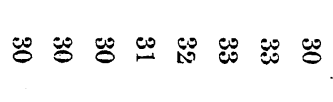 & 帠 \\
\hline 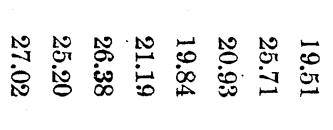 & 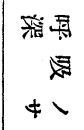 \\
\hline 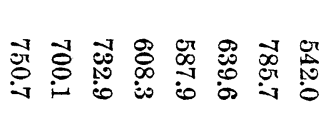 & 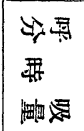 \\
\hline 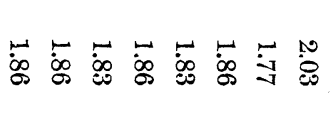 & 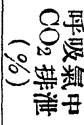 \\
\hline 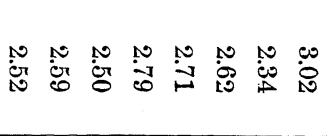 & (2) \\
\hline 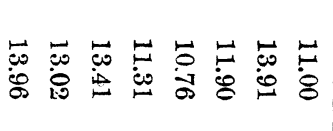 & 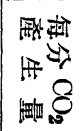 \\
\hline 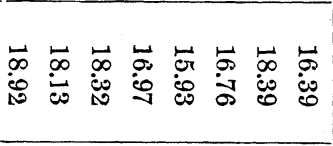 & 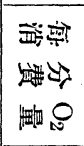 \\
\hline 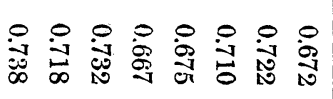 & 震 \\
\hline I 8 \& 8 & 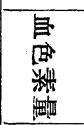 \\
\hline 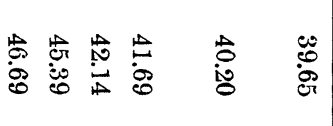 & 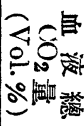 \\
\hline 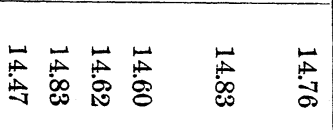 & 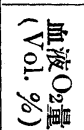 \\
\hline
\end{tabular}

\begin{tabular}{|c|c|}
\hline 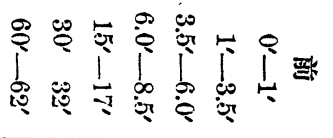 & 形 \\
\hline 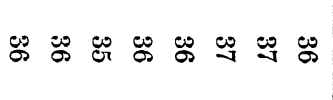 & 费 \\
\hline 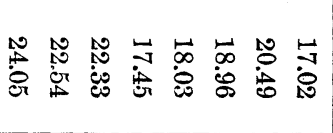 & 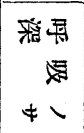 \\
\hline 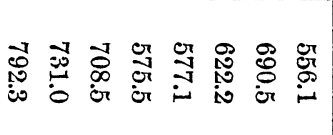 & 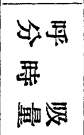 \\
\hline 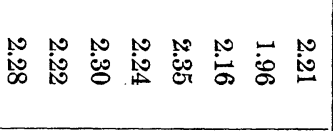 & 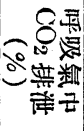 \\
\hline 苟 & 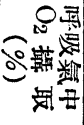 \\
\hline 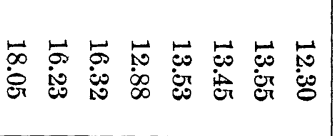 & 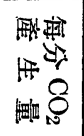 \\
\hline 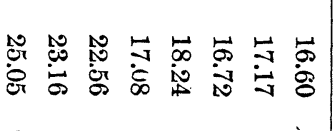 & 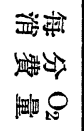 \\
\hline 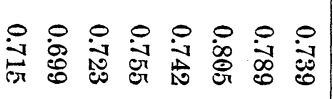 & 蛋 \\
\hline$\vec{w} \not \vec{~}$ & 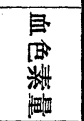 \\
\hline 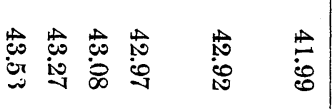 & 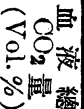 \\
\hline 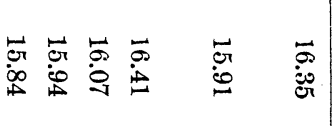 & 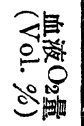 \\
\hline
\end{tabular}




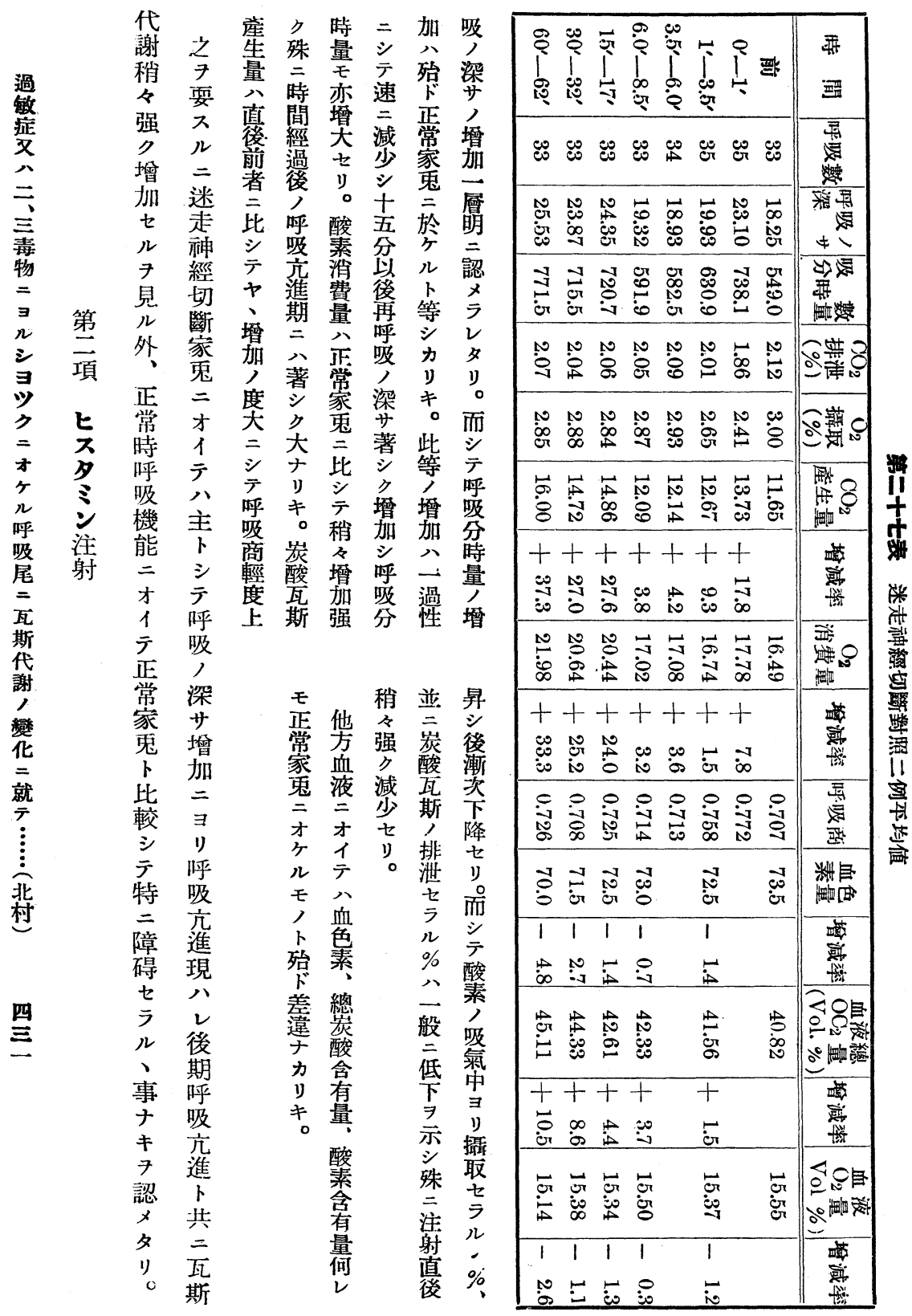




\begin{tabular}{|c|c|}
\hline 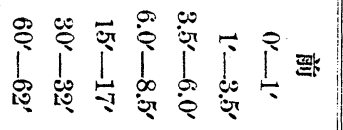 & $\begin{array}{l}\text { 푼 } \\
\text { 표표 }\end{array}$ \\
\hline 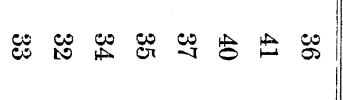 & 搽 \\
\hline 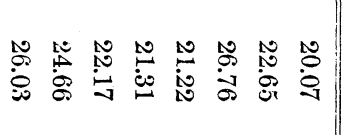 & 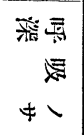 \\
\hline 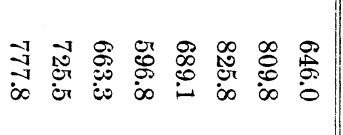 & 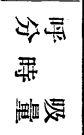 \\
\hline 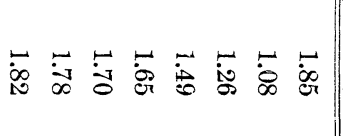 & 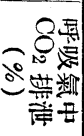 \\
\hline 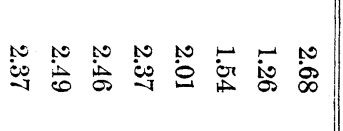 & 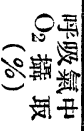 \\
\hline 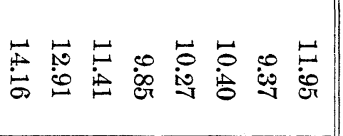 & 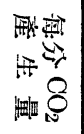 \\
\hline 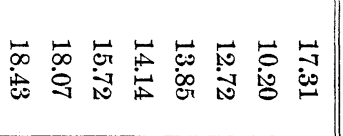 & 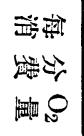 \\
\hline 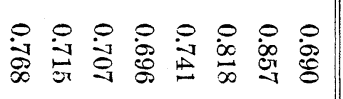 & $\begin{array}{l}\text { 善 } \\
\text { 琶 }\end{array}$ \\
\hline 光 & 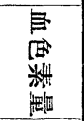 \\
\hline 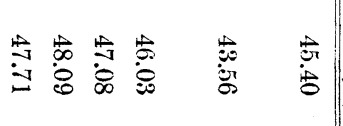 & 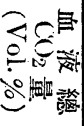 \\
\hline 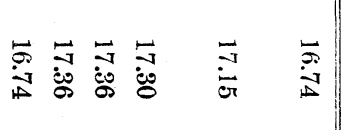 & 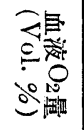 \\
\hline
\end{tabular}

吸分減コ、照カル

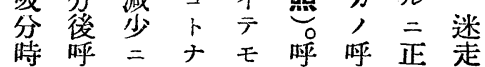
量吸移》注吸吸常神過 八分 $v *$ 射分數家經 敏

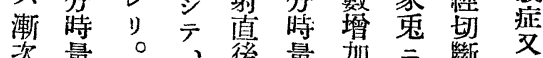
增量從, 後量加三斷 公 加淢紧第增才來方鬼二

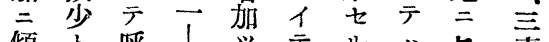
傾卜呼 !ツテル父毒 共吸 三ョ 公二强 從三人穴正過手名=

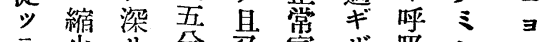
テ少サ分年家ザ吸方n 呼七少後正鬼り嘍 $\bigcirc$ シ 吸》注三常三地堌恶

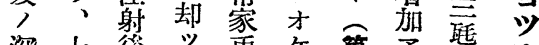
梁十後米々第学》 サ 吾却テ 年 再少具当少三靜方

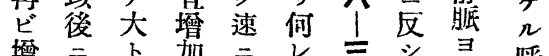
墰 七文、タ少例三極注並

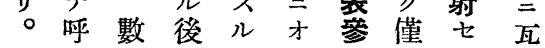

，較七蓄斯常毛少酸謝 後スり。明隹家倘シ、素變

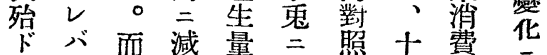
差ソ シ 少至オ筫无量就

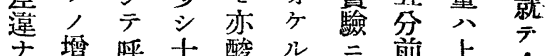
力加吸吾素變才徆述

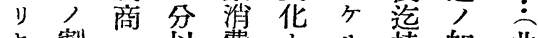

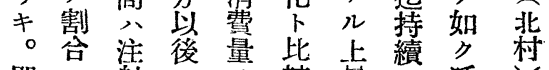

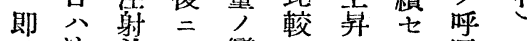
千注前才變 ス 注射 $\exists 1$ 花 $九$ 比後充

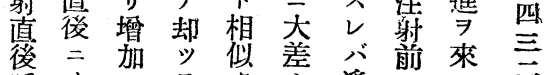

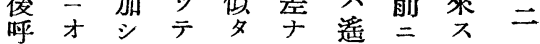

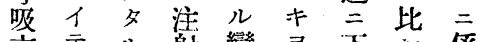
荒テ熦㴬變 進稍 モ 前化認位僅 今 多文 $=x=$ 力 件大正此 シ 七ナ常シテリリラ後 炭り家增 即。要

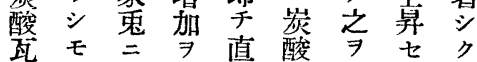
斯\%比示後旊正儿減 


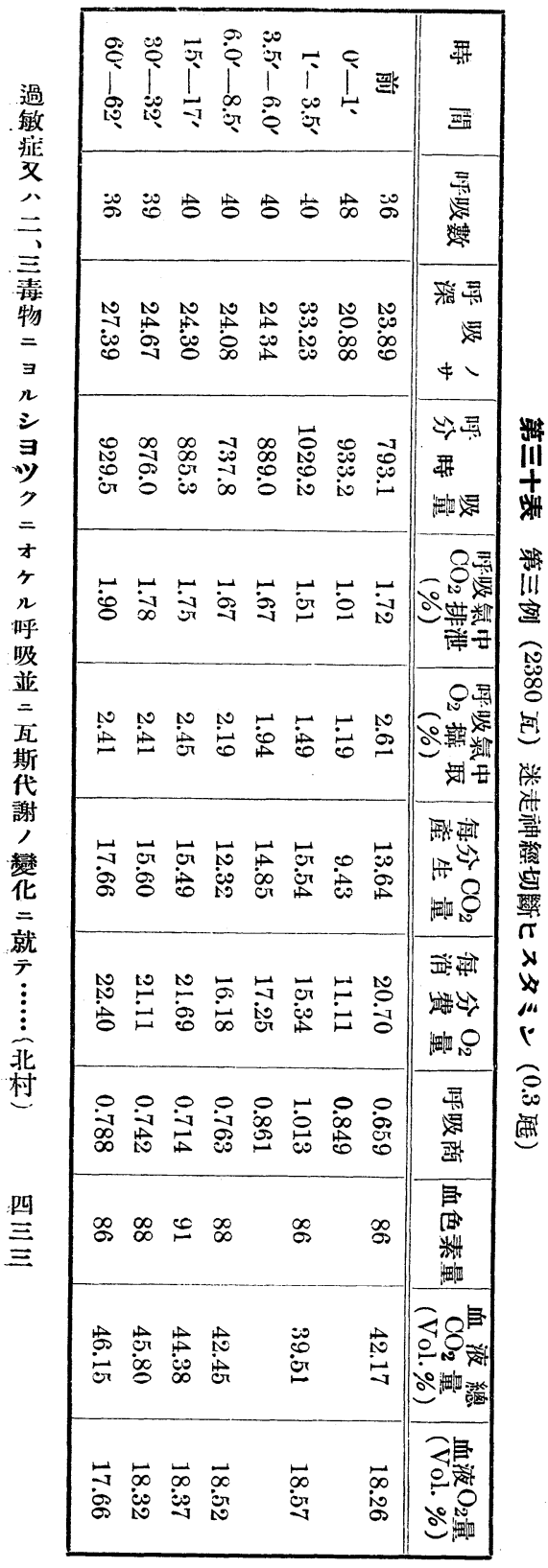

\begin{tabular}{|c|c|}
\hline 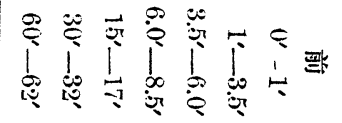 & 形 \\
\hline 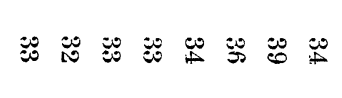 & 震 \\
\hline 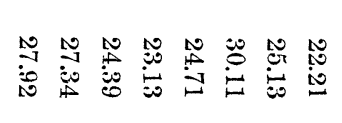 & 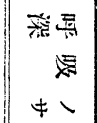 \\
\hline 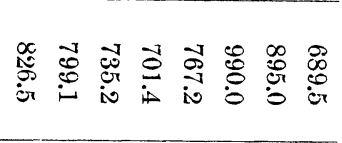 & 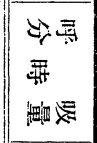 \\
\hline 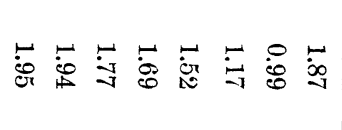 & 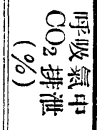 \\
\hline 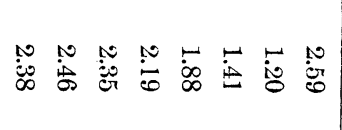 & 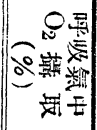 \\
\hline 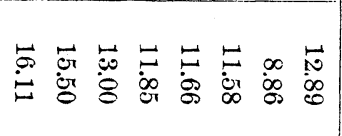 & 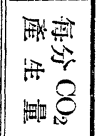 \\
\hline 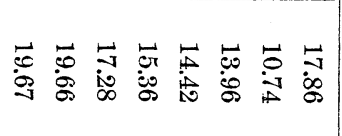 & 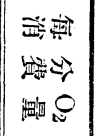 \\
\hline 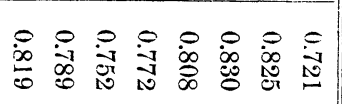 & 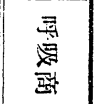 \\
\hline બૈ ปૈ ન્ર & 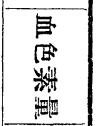 \\
\hline 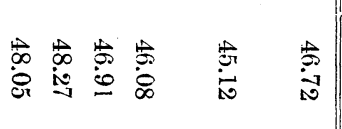 & 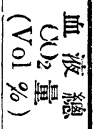 \\
\hline 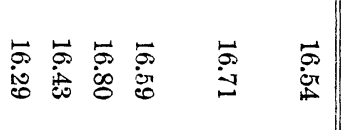 & 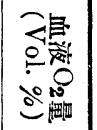 \\
\hline
\end{tabular}




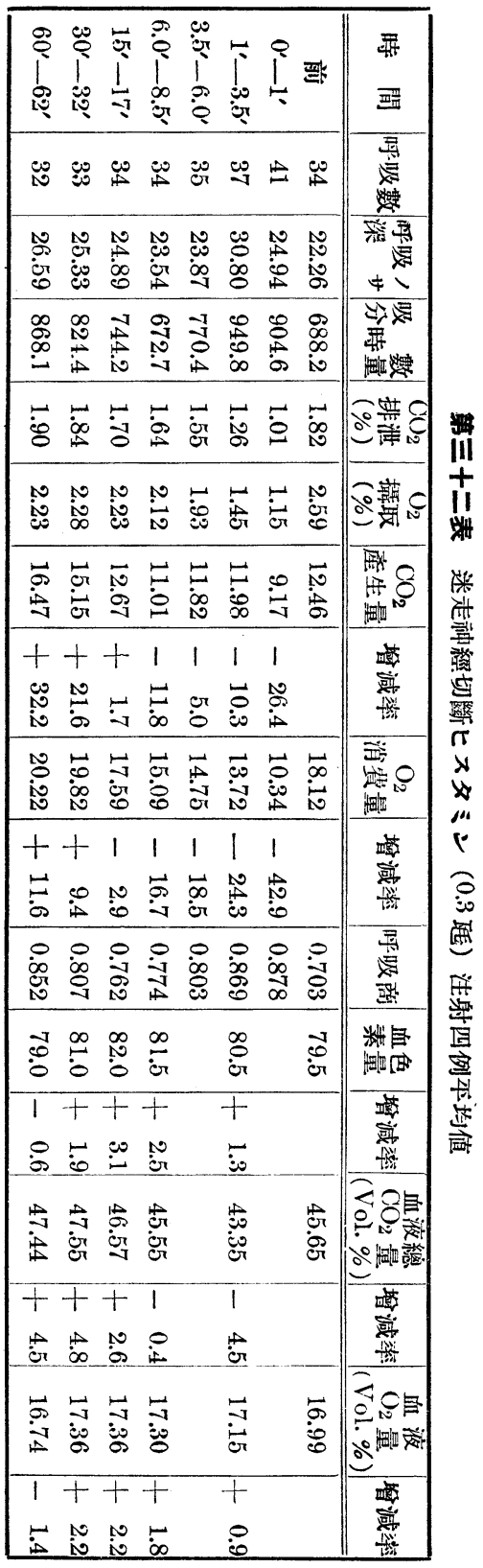

\begin{tabular}{|c|c|}
\hline 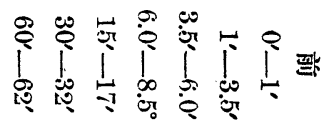 & 평 \\
\hline 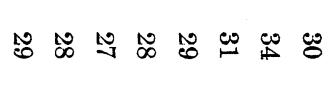 & 長 \\
\hline 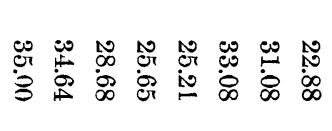 & 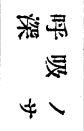 \\
\hline 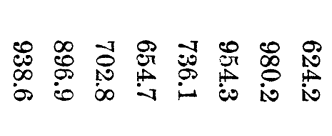 & 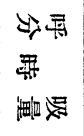 \\
\hline 店 & 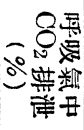 \\
\hline 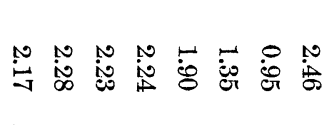 & D氞 \\
\hline 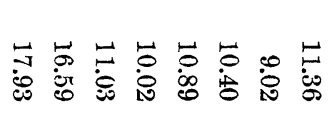 & 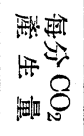 \\
\hline 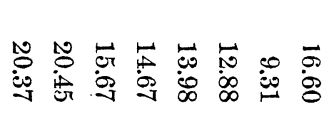 & 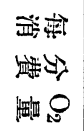 \\
\hline 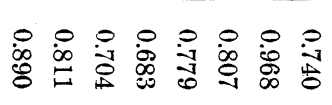 & 余 \\
\hline 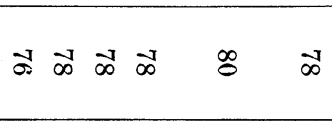 & 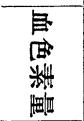 \\
\hline 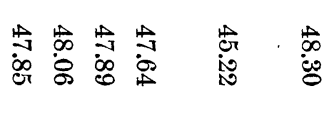 & 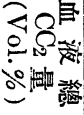 \\
\hline 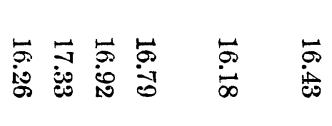 & 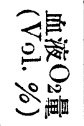 \\
\hline
\end{tabular}


化才三7 分 迷 テ

シ1锤問時走强以

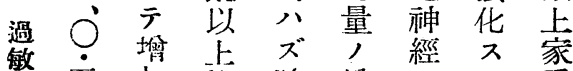
症五加注始增 $7 ル$ 兔 及 玨大射 $ト$ 加切呼 八注ナス同分斷吸 ス 二射りル 樣 正 七數》 三例 キ時) 常ルノ文 毒二 0 增 變家家著 ン 物才動加化鬼鬼明 シ $=1$ 胍 傾 7 二ナヨ 寻血向示才称 秒中認シ ケ不增ク ヨト總メ 、ルテ加二 当酸炭ラ 即ヨハ7 オ

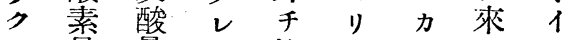
む量量、注毛、合方 オ人而射稍ル、得 ヶ比娍方直々呼呼夕 呼輍少テ後大吸吸ル 吸的傾七急十分結 並減向 万激 ル變時果 二少 $タ ー タ$ 化量 瓦來示ミ著認心二通 斯レスンシ シ $ン$ 起才覽

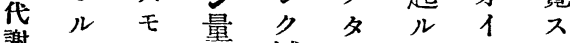
謝 7 大減りコテル 變認多ナ少。卜小二 化 カ九再等增正 = タリ程り斯》、加常 就りキコ代、僅芜 テ ○、而謝只少雭 $\vdots$ 酸 傾 シ 北系向 テ 正二過才

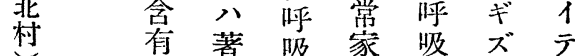
量 明阔 兔 數、公 八ナ八タ 增呼注 四血り輕ル加吸射

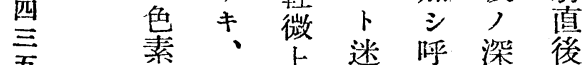

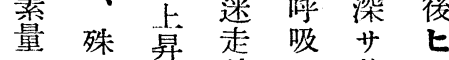
二 二 七神, 著 䅛迷り經深 シ 夕 減走。切サク主 二神 血芜增 小覍

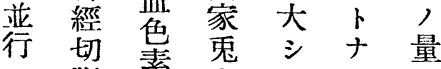
シ 断 素 變
認出之呼ざ量韮

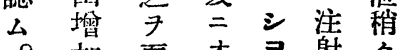

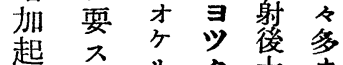

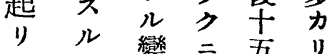
血篟 才永 血 迷 = 迄 $\Rightarrow$ 色走二 $、$ 漸認

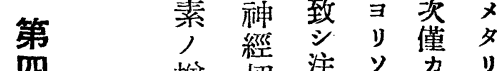
四增 切注, 宛宛 章加斷射增堌血

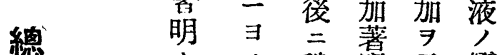
括 ト リ 稍奛 示變 及 $り$ 減 票二

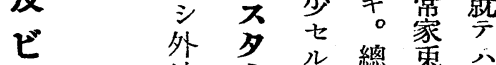
考迷ミ後魏公先 按神特對量 ス 血 經有照公夕色 切, =外三素

断 呼

八吸

互, 酸 7 比 斯 變 素 示較 代华容名 謝消量名層 並失樰モ緻 二 シ 加 徐 肺 $=$ 小 注對增儿 瓦射 礁 加增 斯直 ス 率 加 交後沓寻省 換呼, 見 二吸年学多 對充 シ 血》 本進察境酸 質レ明增素 的血 加含 變 液 得 三 有 化岸 シ 当量 7 酸 。广 輕 來, 來度 ザ輕 㹂墰 


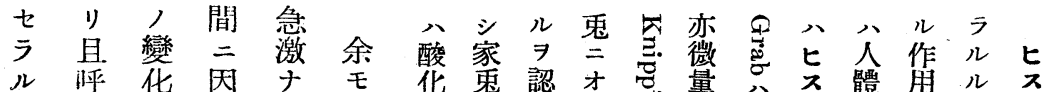

、收 7 果ル 亦作七文

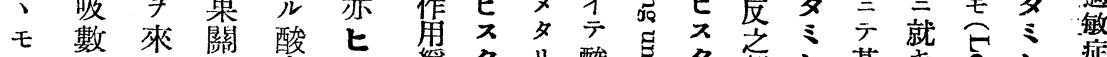

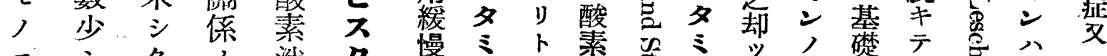

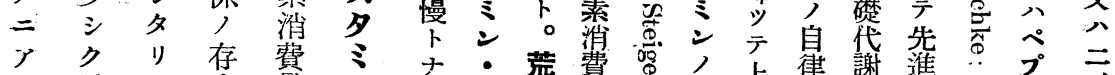

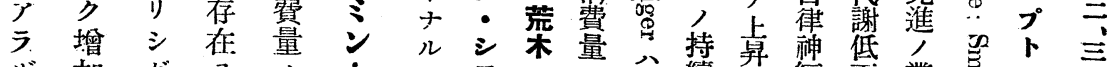

ザ 加 ガ フ く

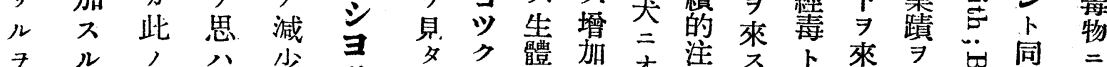

チル ハ 少

知ノ際 $シ$ 起

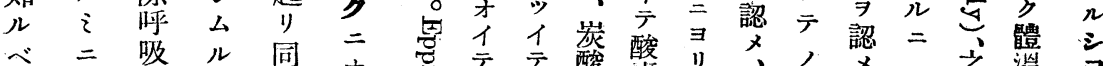

ベ ニ 吸

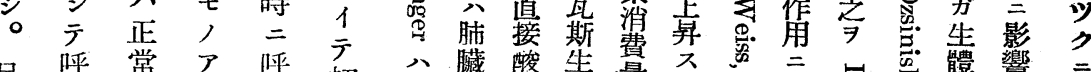

且呼常 ア 呼家

七吸 冢

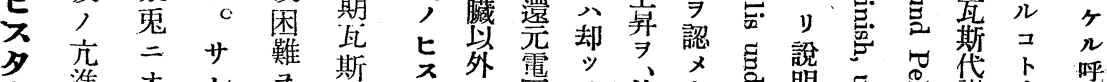

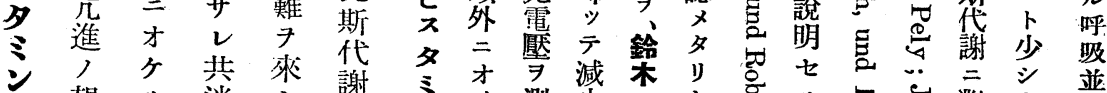

ン 想ル 迷 シ 謝 ミ オ

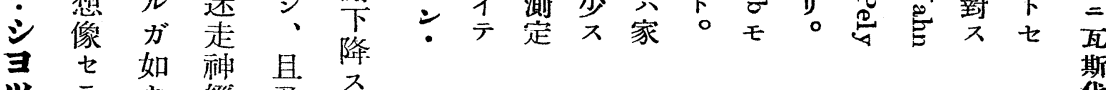

ツ キ 經文 ス

クル 淺切 两

代

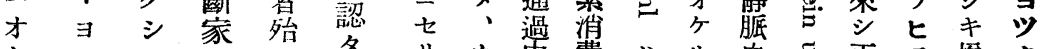

ヶ リ ラ 兔

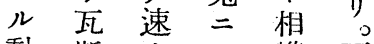

動斯ナ方携而

胍代ル化へヘ

血謝 呼 テ テ テ

, 低吸 八回余

瓦下起正復,

斯ガル常 ス 䚀

組とコ家ル驗

成 スト兔ガ成

二タナト 如績

殆ミク殆キキ キ

トン・ド經詩

全呼却全過細

ク 吸 ツ ク $ッ$ 二

變困テ同辿見

化難 呼樣り ル

ナ二昅, テ 二

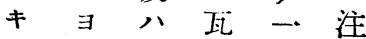

二 リ深 斯 見 射

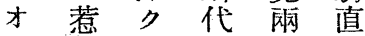

1 起ナ謝者後

ル 濃 量著, 酸

細儿ク肢用儿邑蔯二シ 初

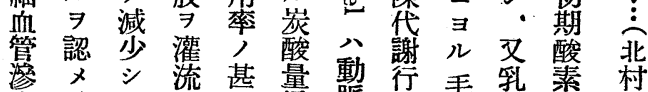

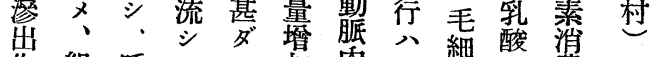

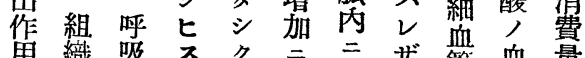

用 織 吸 スク ニ ザ管 血 量

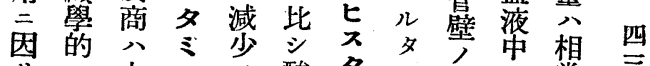

酸毛年, ル酸ダ

素細 ス大 $\Rightarrow$ 光來化齐少

擴血儿量認減 7 ルノクシ

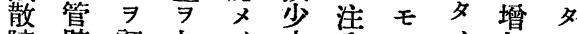

障壁認加少入, 入加

䅞人メフ品》不卜酸セ

セ浮又儿哓、ルナ素儿 其

ラ 腫 血洔等即時七供 $\ni$ 後

ルア 液公手永少給認却

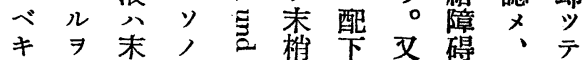




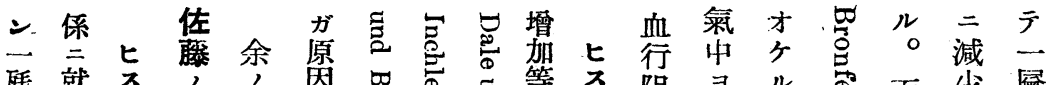

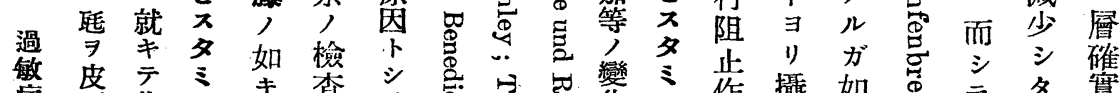

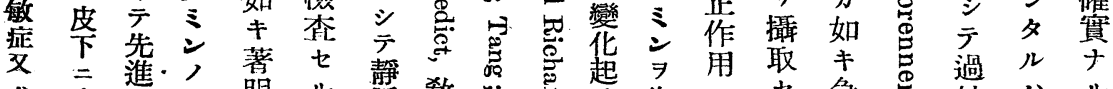

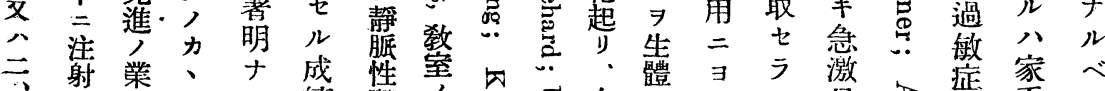

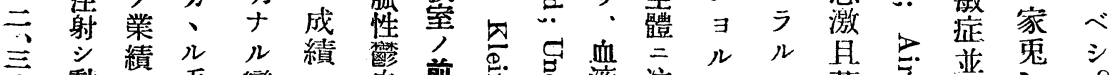

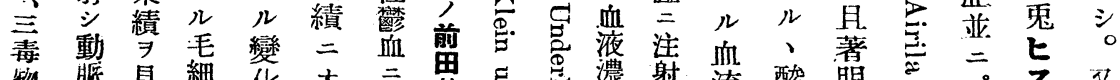

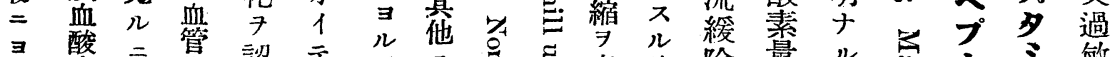

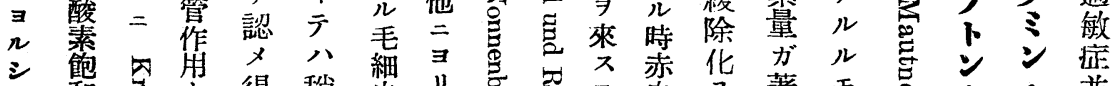

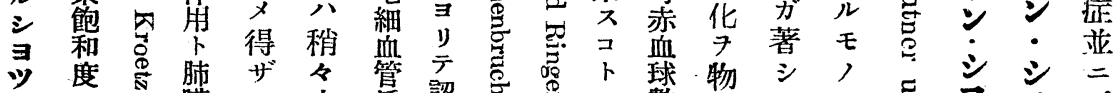

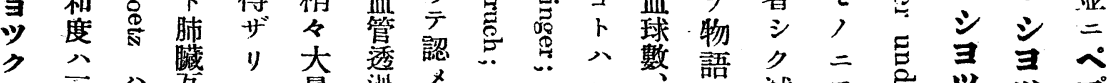

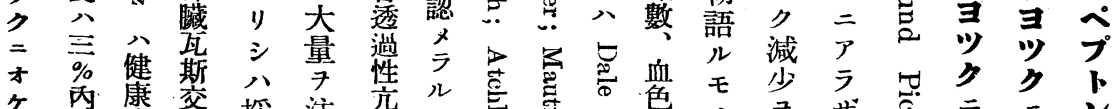

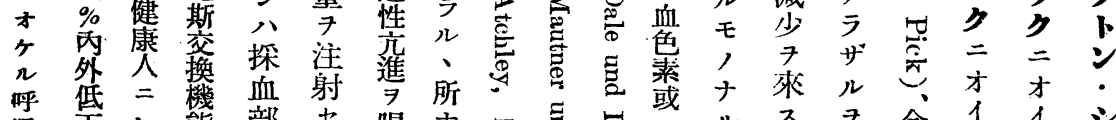

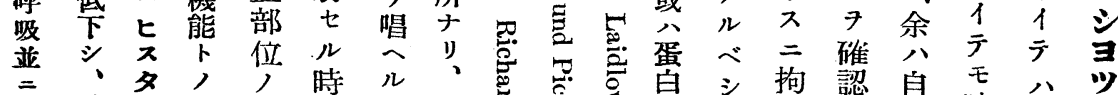

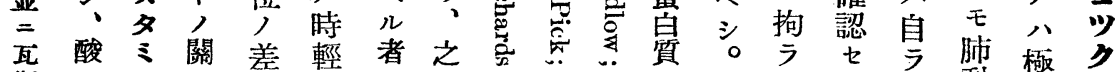

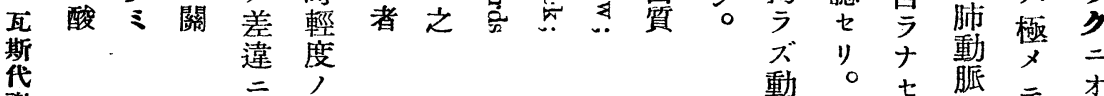

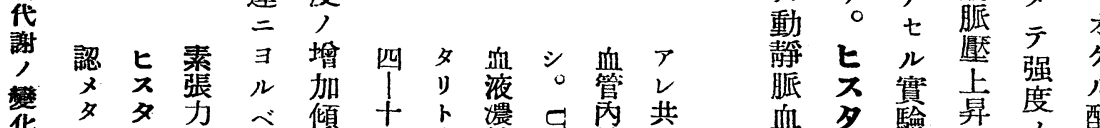

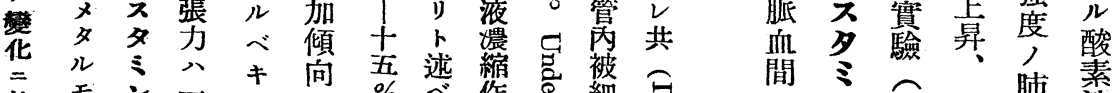

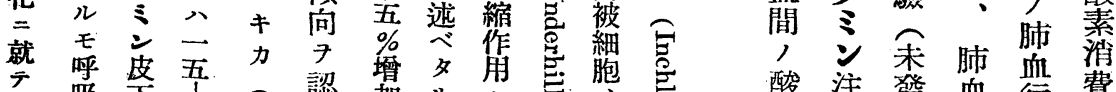

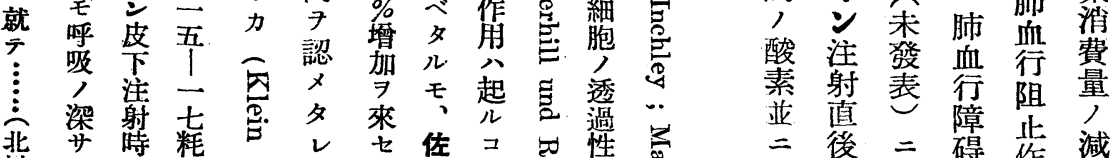

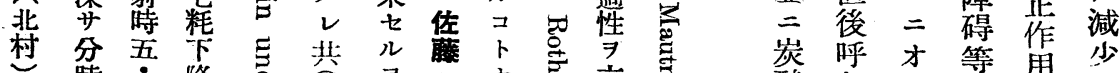

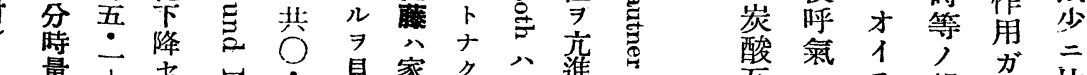

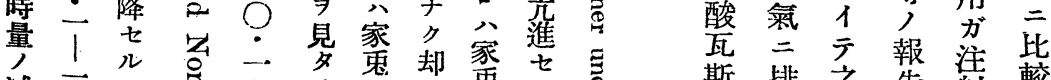

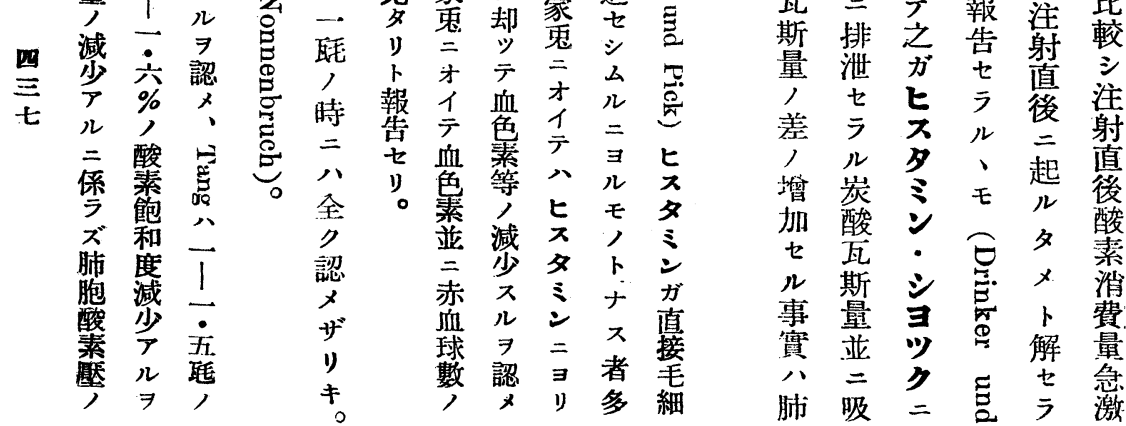




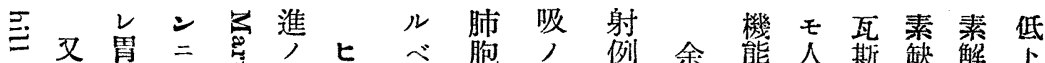

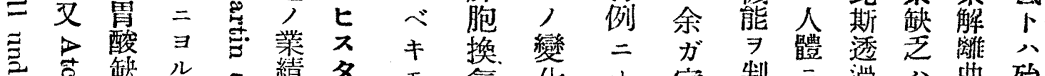

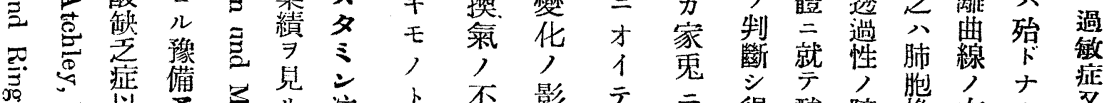

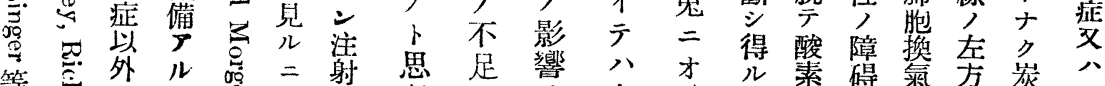

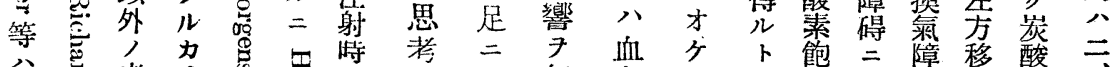

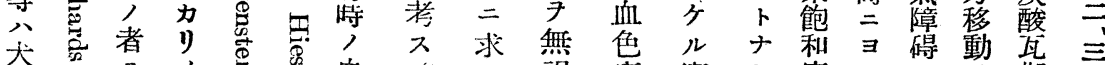

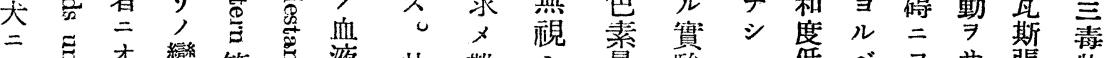

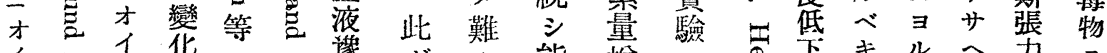

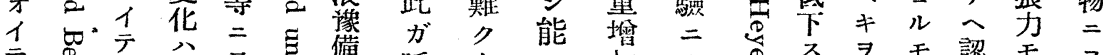

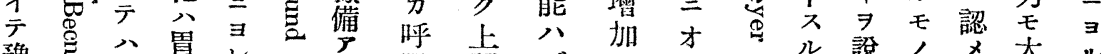

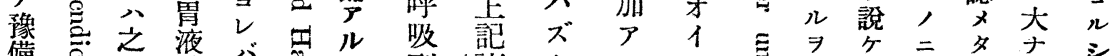

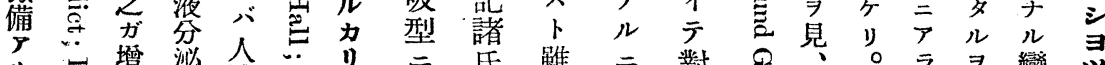

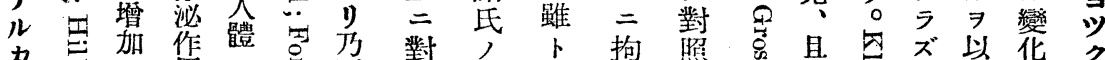

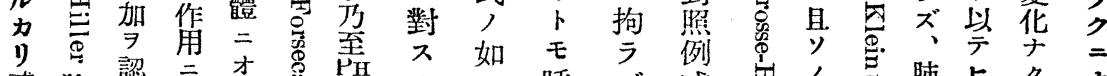
或 公总

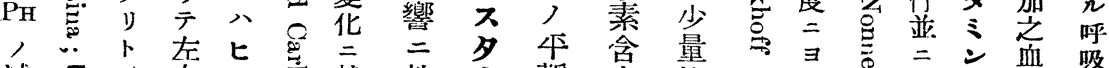

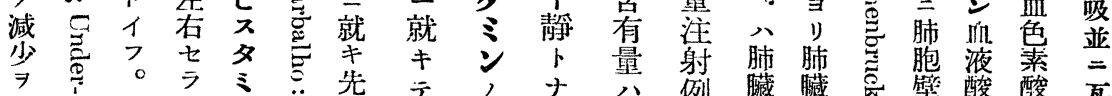
筀酸 酸 再 却二

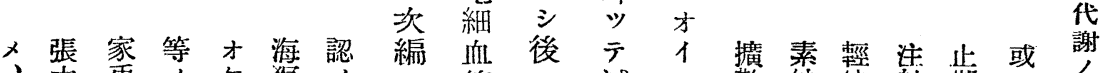

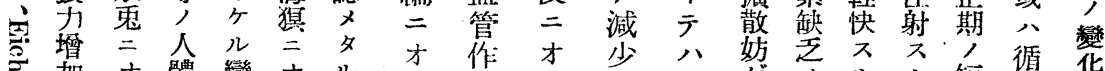

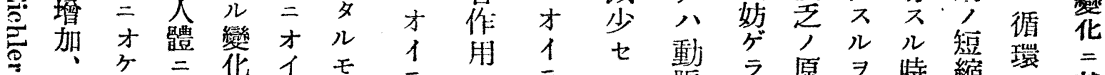

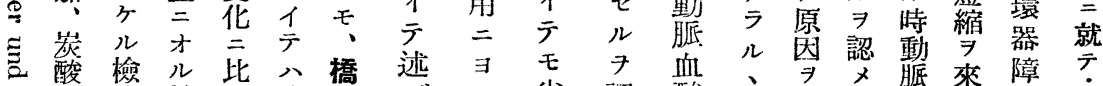

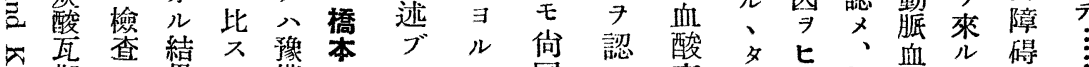

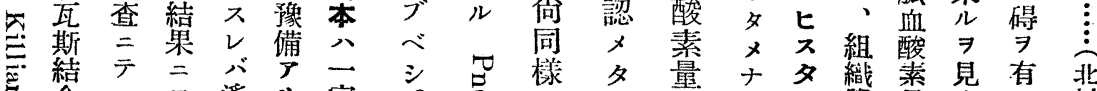

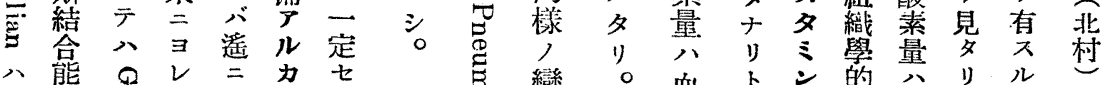

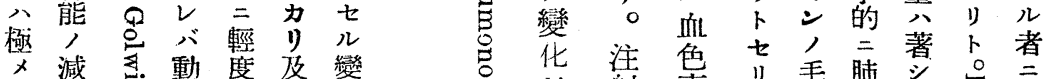

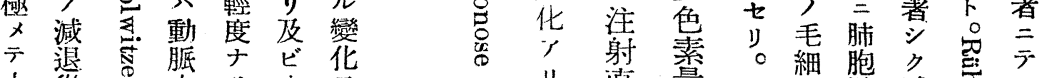

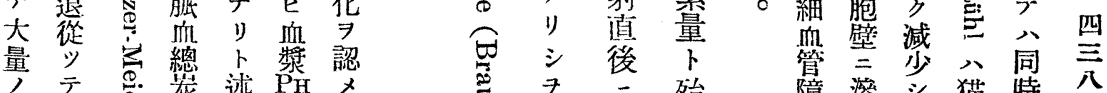

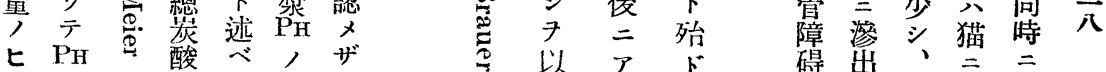
ス, 八必減》 夕減動增り少 キ 三少脈隇。学卜

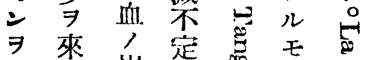

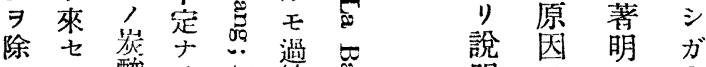

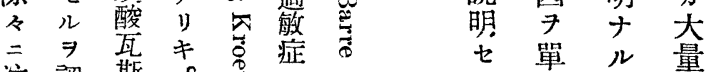
注認斯节离症, ラ = 呼注
䅞出、 $=$ 腺 酸 天 肺 $\exists \Rightarrow$ 絭量活

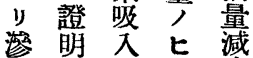
越令学少 起力

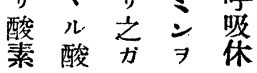




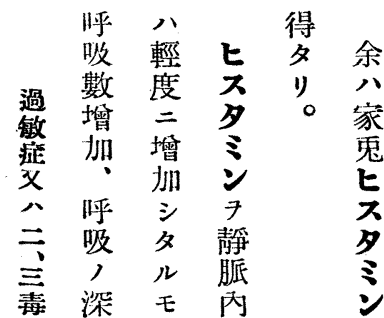

物サ速注

$=$ 二 射

寻增 減

卡大少ル

$\exists$ 二 時

呼移

>吸值

＼cjkstart分少二

才時。㭔

ヶ 量 迷 吸

呼主困

吸塔 神難

並加經 來

= 7 切

瓦認断 呼

斯

代夕兔 數

謝り

篟 酸 正 ク

二素常增

就沙家 加

テ費 兔 ス

! 量 二

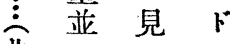

北

村炭呼呼 酸 昅昅 瓦,

四斯 變 深

四离化 サ

兄生 量認減

小又少

過 ラ 七

敏レリ

正 ズ

沙僅 呼

$=$ 二 吸

$\rightarrow$ 慙 分
- 第虑代進 テ 定

シ 五 セ謝二小方

$\exists$

巣

要

牙

r

ル

拏

吸 論

瓦

代

謝

血

留

斯

血

色

量

變

化

就

キ

檢

索

7

+

シ

次

'

結 酸。儿以 減力所上 少、ナ ルル 注 ク 細

$卜$ 血 $上$

部䄧 多 二 原充注示 酸 組 色 7 代人增 謝, 加 ラ

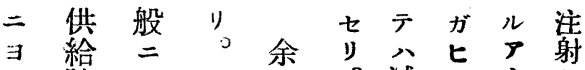

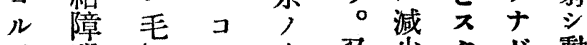

$\boldsymbol{ア}$ 碍細, 家又少タド動

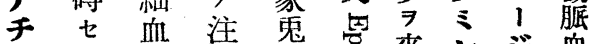

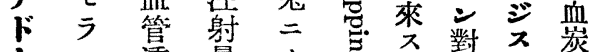

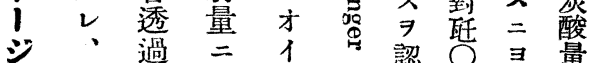

ス酸性才六認 ○寻量 犬 血 七管五, シ

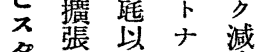
冬登或贞貿 专或少不

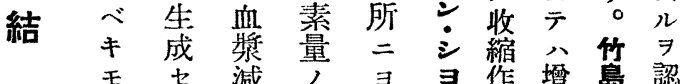

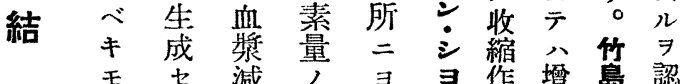

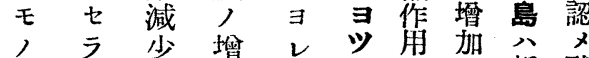

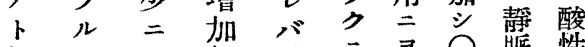
信 今 $\Xi$ 倾. 動 賞

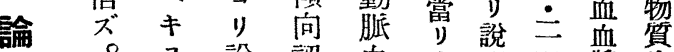
7 說認 血 血明 玨漿星 以明 $\checkmark$ 總 中七以總成

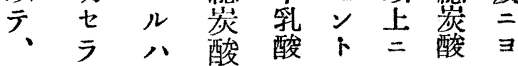
動 ル 既 八 脈少所述? 血總 所 述 炭り夕助 少毛モ 射

モ 管 ス 時 部性 シ 1

因進 射減 卜, 時少 シ 为, 傾 テ メ 血 向 性 織 素 認

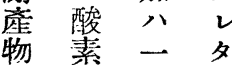

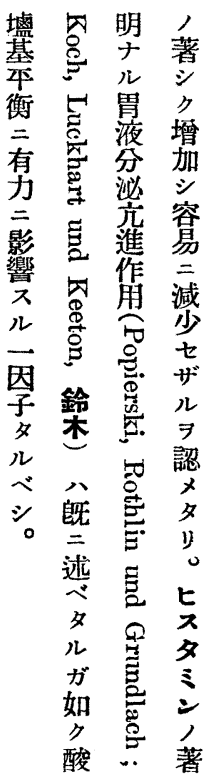




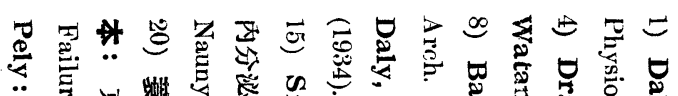

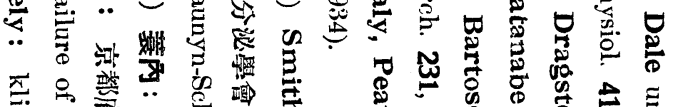

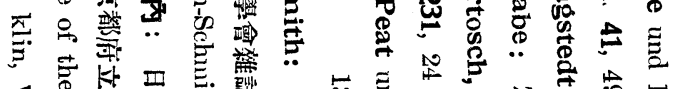

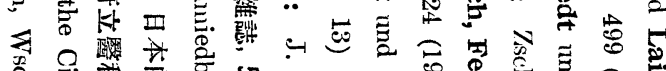

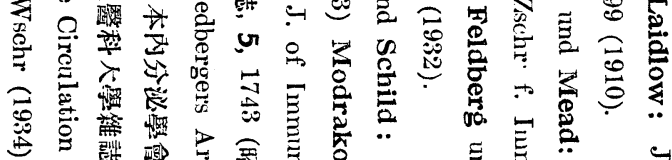

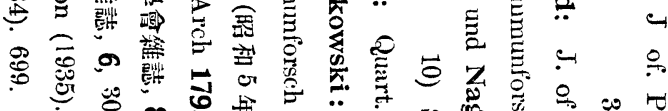

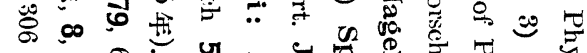

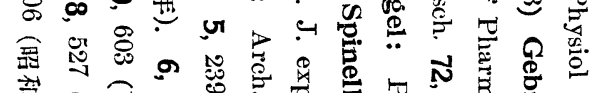

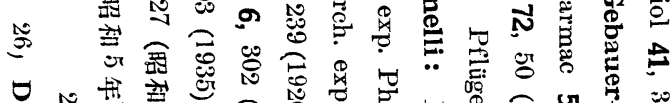

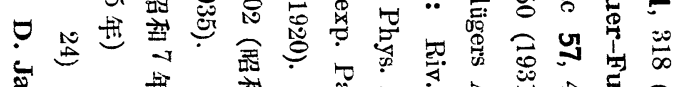

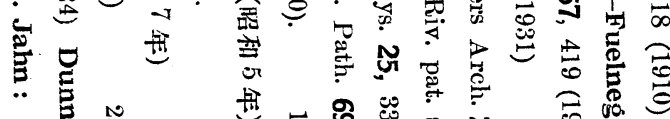

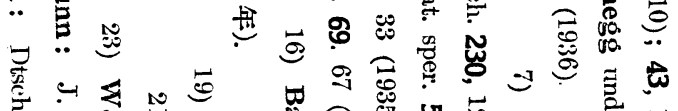

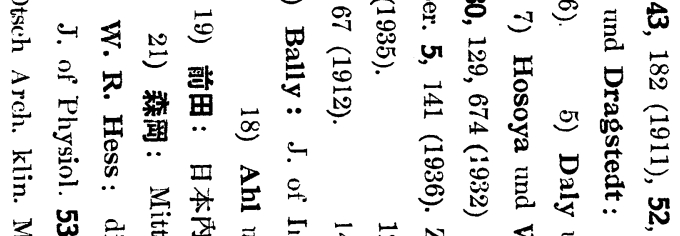

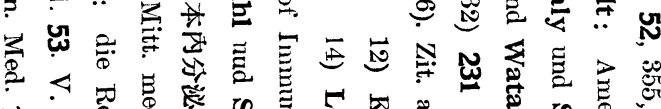

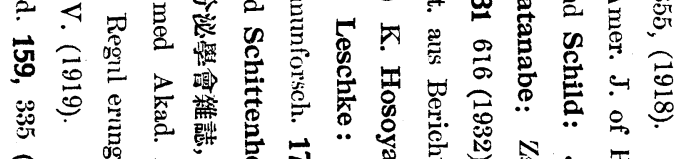

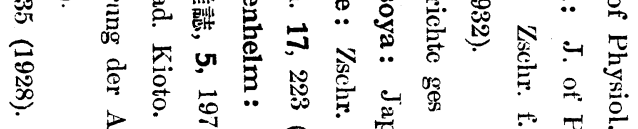

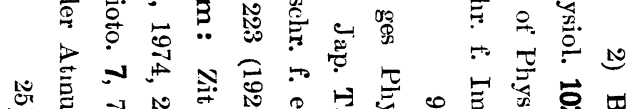

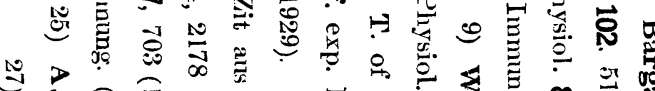

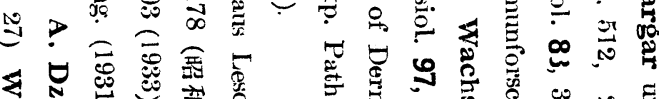

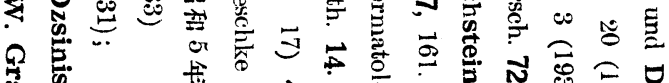

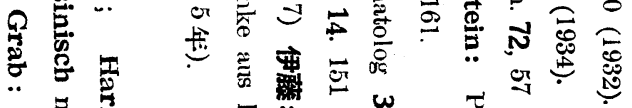

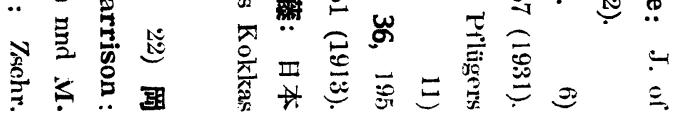

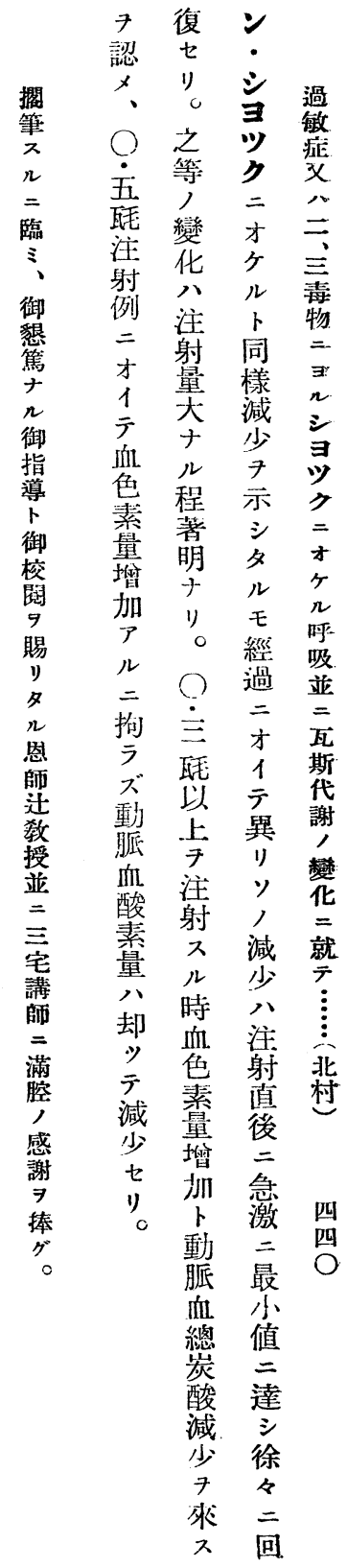




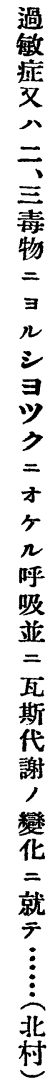

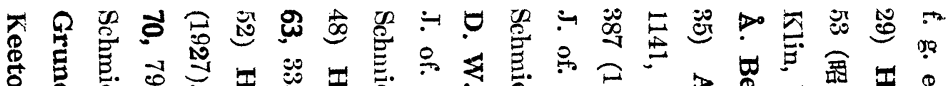

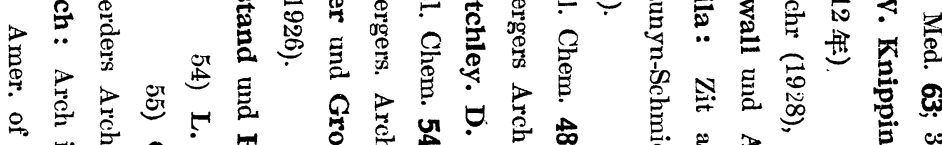

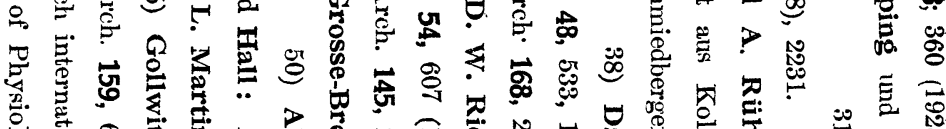

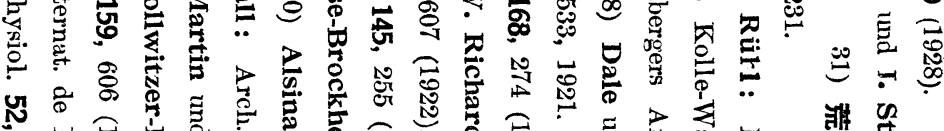
N

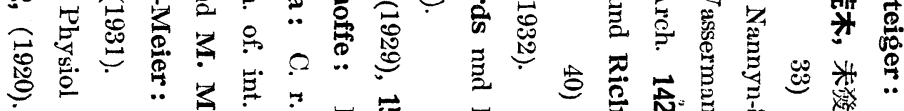

四

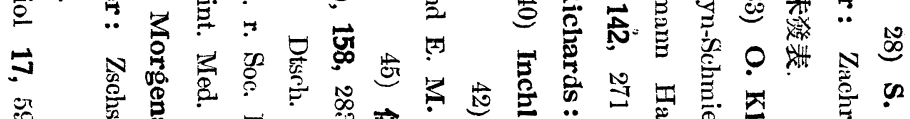

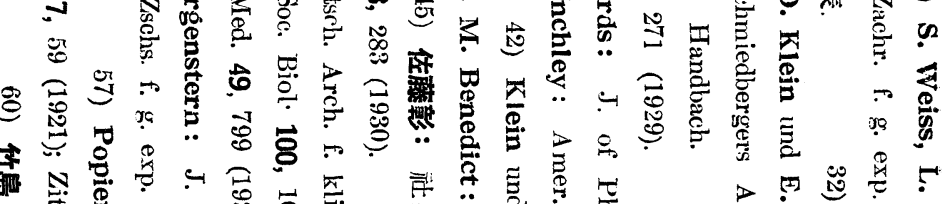

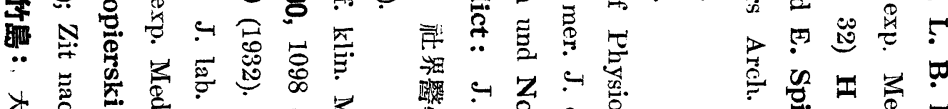

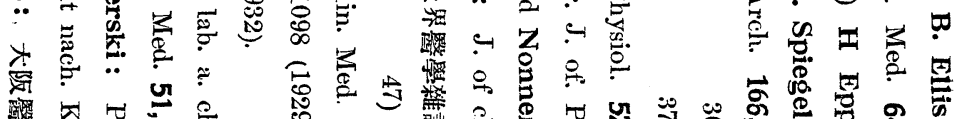

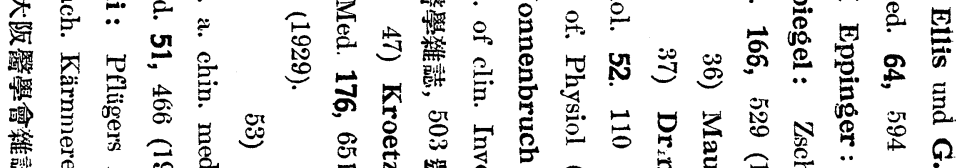

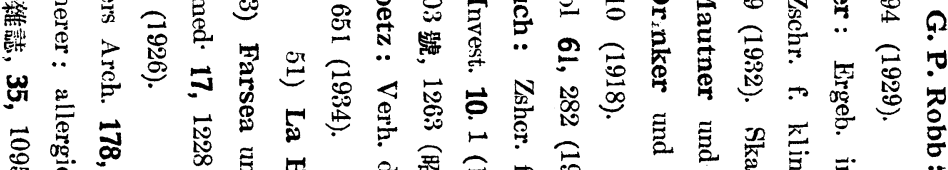

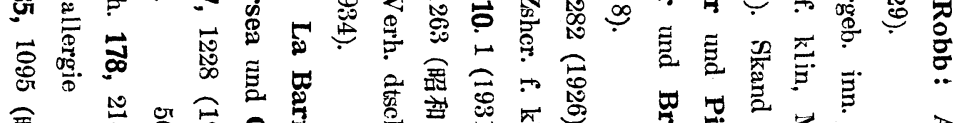

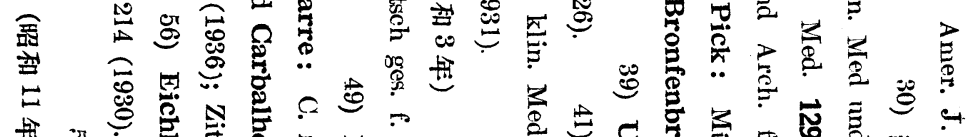

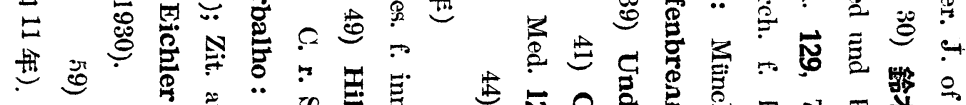

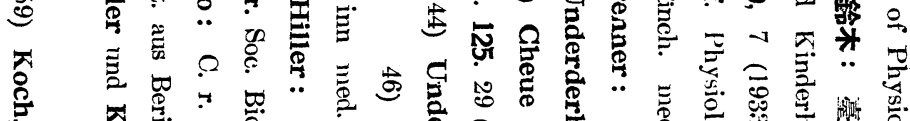

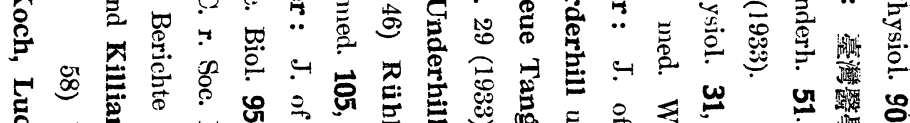
范

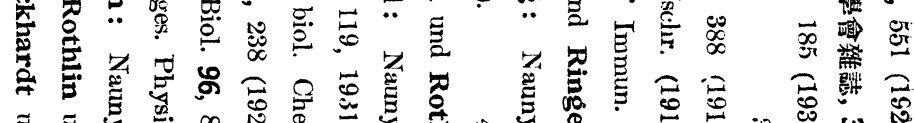

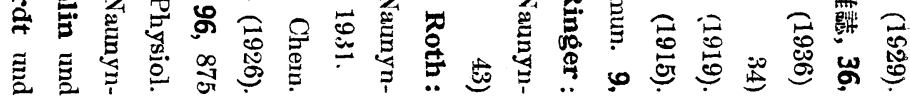


vorgerufen wurde, war Atmbeschleunigung stärker ausgeprägt und längerdauernd im Vergleich mit normalen Kaninchen. Trotzdem war der Gaswechsel auffallend herabgesetzt, der respiratorische Quotient war deutlich erhöht. Arterieller Gesamtkohlensäuregehalt verminderte sich sofort nach der Reinjektion in gleicher Weise, wie beim normalen Kaninchen. Aber diese Abnahme dauerte ca 15 Minuten an, während sie beim normalen Kaninchen in derselben Zeit bereits wieder allmählich in die Zunahme übergeht. Der Hämoglobingehalt des arteriellen Blutes zeigte bei der Hälfte der Fälle leichtgradige Zunahme. Mit dem arteriellen Sauerstoffgehalt liess sich kein wesentlicher Unterschied zwischen serumanaphylaktischem und normalem Tier beobachten.

3. Kaninchen, welchen $1-1.2 \mathrm{~g}$ Witte-Pepton intravenös beigebracht wurde, zeigten Atembeschleunigung-kenntlich in der $\mathrm{Zu}$ nahme von Frequenz und Minutenvolumen-Verminderung des Sauer stoffverbrauches, erhöhten respiratorischen Quotient, leichte Abnahme der Gesamtkohlensäure des arteriellen Blutes, leichte Zunahme von Hämoglobingehalt und dem parallel gehenden Sauerstoffgehalt des arteriellen Blutes. Die Kohlensäureproduktion in der ausgeatmeten Luft war in einigen Fällen vermehrt, in anderen dagegen vermindert.

In allen Punkten war beim Pepton-schock stets dasselbe Verhältnis nachweisbar wie bei Serumanaphylaxie, jedoch in schwächerem Ausmasse.

(Autoreferat)

\section{Über die Veränderungen der Atmung und des Gaswechsels beim serumanaphylaktischen und beim durch einige Kapillargifte hervorgerufenen Shockzustand.}

II. Mitt. Histaminshock.

Von

Dr. R. Kitamura.

(Aus der 1. Med. Klinik der Kaiserl. Universität zu Kyoto in Japan Direktor : Prof, Dr. K. Tsuji) 
Die Versuchsanordnungen sind wie beim Anaphylaxieversuch (Mitteil. I.). Spritzt man einem normalen Kaninchen 0,1—0,5 mg Histamin ein, so erfährt die Atmung starke Beschleunigung, was sich in der Frequenzzunahme und leichten Erhöhung des Minutenvolumens äussert. Beim vagotomierten Tier liess sich dagegen keine Frequenzzunahme der Atmung nach Histamininjektion feststellen. In beiden Fällen sank zwar der Gaswechsel sehr steil sofort nach der Injektion, und der respiratorische Quotient erfuhr leichte Erhöhung. Diese plötzliche Herabsetzung des Gaswechsels ist wahrscheinlich auf die durch Histamin hervorgerufene Lungensperre zurückzuführen. Wenn mehr als $0,3 \mathrm{mg}$ Histamin einverleibt wurde, so kam es im arteriellen Blut zur leichten Verminderung des Gesamtkohlensäuregehaltes uud zur Zunahme des Hämoglobingehaltes. Spritzte man 0,5 mg Histamin, dann sank der Sauerstoffgehalt des arteriellen Blutes. Dieses Herabsinken war noch im späteren Stadium nachweisbar, wo fast keine Atembeschleunigung zu beobachten war.

Die in diesem und im I. Versuch beobachtete Zunahme des Hämoglobingehaltes im arteriellen Blut ist höchstwahrscheinlich durch Blutplasmaverlust, der sich auf dem Boden der Kapillarpermeabilitätssteigerung entwickelt, bedingt.

(Autoreferat) 